\title{
ARTIK DEĞERE (TMK MD.237 F.2) VE ORTAKLIK MALLARINA (TMK MD.276 F.3) KATILMA ANLAŞMALARIYLA SAKLI PAY KURALLARININ BERTARAF EDÍLMESI: BİR MEDENİ HUKUK ANOMALİSI
}

\author{
ELIMINATING STATUTORY INDEFEASIBLE ENTITLEMENTS \\ MAKING MARITAL AGREEMENTS ON PARTICIPATION IN THE \\ SURPLUS (TCC ART.237 PARAG.2) AND COMMON PROPERTY (TCC \\ ART.276 PARAG.3): A CIVIL LAW ANOMALY
}

DOI: $10.21492 /$ inuhfd.388339

Tuba BİRİNCİ UZUN*

\section{Özet}

4721 sayılı Türk Medeni Kanunu'nda edinilmiş mallara katılma rejimi, yasal mal rejimi olarak benimsenmiştir. Edinilmiş mallara katılma rejiminde, eşlerden her biri veya evlilik birliğinin ölümle sona ermesi halinde mirasçıları, artık değerin yarısı üzerinde hak sahibi olurlar. Artık değere katılma anlaşmalarıyla başka bir oranın belirlenmesi mümkündür. TMK md.237 f.2 hükmünde, "Bu tür anlaşmalar, eşlerin ortak olmayan çocuklarının ve onların altsoylarının saklı paylarını zedeleyemez" denmektedir. Benzer bir düzenleme, seçimlik mal rejimlerinden mal ortaklığg bakımından da söz konusudur. TMK md.276 hükmünde "Eşlerden birinin ölümü veya diğer bir mal rejiminin kabulü sebebiyle mal ortaklı̆̆ının sona ermesi hâlinde, her eşe veya mirasçılarına ortaklık mallarının yarısı verilir. Mal rejimi sözleşmesiyle başka bir paylaşma oranı kararlaştırılabilir. Bu tür anlaşmalar altsoyun saklı payların zedeleyemez” denmektedir. Artık değere ve ortaklık mallarına katılma anlaşmalarına ilişkin bu düzenlemeler (TMK md.237 f.2 ve md.276 f.3), Türk Medeni Kanunu'nda benimsenen miras hukuku sistemiyle uyumlu değildir. Ayrica bu düzenlemeler, kanun koyucunun amacını aşan sonuçların ortaya çıkmasına neden olmaktadir.

Anahtar Kelimeler: Edinilmiş mallara katılma rejimi, mal ortaklığı rejimi, saklı paylı mirasçılık, mirasta denkleştirme, ölüme bağlı tasarruf.

\section{Abstract}

According to Turkish Civil Code (TCC) (Law No.4721), the regime of participation in acquired property is the statutory marital property regime. In this property regime, each spouse or his or her heirs is or are entitled to one-half of the surplus of the other spouse. A different participation in the surplus may be agreed by marital agreement. In the article 237 paragraph 2 of TCC, it is stated that "Such agreements must not adversely affect the statutory inheritance entitlements of children who are not the common issue of the spouses or those of the issue of such children". In the regime of community of property which is an optional marital property regime, there is a similar provision. In the

\footnotetext{
* Dr. Öğr. Üyesi, Akdeniz Üniversitesi, Hukuk Fakültesi, Medeni Hukuk Ana Bilim Dalı

Öğretim Üyesi. tbirinciuzun@akdeniz.edu.tr

Makale Gönderilme Tarihi: 01.02.2018

Makale Kabul Tarihi: 04.04.2018
} 
article 276 of TCC, it is stated that "If the community of property regime is dissolved by the death of a spouse or the implementation of a different marital property regime, each party or his or her heirs is entitled to one-half of the common property. A different method of division may be agreed by marital agreement. Such agreements must not adversely affect the statutory inheritance entitlements of the spouse's issue". These provisions (TCC art. 237 parag. 2 and art.276 parag.3) do not comply with the system founded by inheritance law regulated in TCC. Besides these provisions emerge some consequences which go beyond the purpose of the legislature.

Keywords: The regime of participation in acquired property, the regime of community of property, statutory indefeasible entitlements, hotchpot duty of the heirs, testamentary disposition.

\section{Giriş}

Mirasbırakanın terekesi üzerinde külli halef sıfatıyla hak sahibi olan kişiye mirasçı denir ${ }^{1}$. Mirasçılık sıfatı ya kanundan doğar ya da mirasbırakanın iradesine dayanır. Buna göre, iki çeşit mirasçı vardır. Birincisi, yasal mirasçıdır; ikincisi, atanmış mirasçıdır. Mirasbırakanın yasal mirasçıları, birinci zümrede onun altsoyudur (TMK md.495 f.1). Mirasbırakandan önce ölmüş olan çocukların yerini, her derecede halefiyet yoluyla kendi altsoyları alır (TMK md.495 f.3). Mirasbırakanın yasal mirasçıları, ikinci zümrede onun ana ve babasıdır (TMK md.496 f.1). Mirasbırakandan önce ölmüss olan ana ve babanın yerlerini, her derecede halefiyet yoluyla kendi altsoyları alır (TMK md.496 f.2). Altsoyu, ana ve babası ve onların altsoyu bulunmayan mirasbirakanın mirasçıları, büyük ana ve büyük babalardır (TMK md.497 f.1). Mirasbırakandan önce ölmüş olan büyük ana ve büyükbabaların yerlerini, her derecede halefiyet yoluyla kendi altsoyları alır (TMK md.497 f.2). Bunlar, mirasbırakanın üçüncü zümre yasal mirasçılarıdır. TMK md.499 uyarınca, sağ kalan eş de mirasbırakanın yasal mirasçılarındandır.

Yasal mirasçılardan bazıları, saklı paylı mirasçıdır. Saklı pay, mirasbırakanın üzerinde tasarrufta bulunamayacağı miras payıdır. Başka bir deyişle, saklı pay bertaraf edilemeyen miras payıdır². Saklı paylı

\footnotetext{
${ }^{1}$ İMRE, Zahit/ERMAN, Hasan: Miras Hukuku, 10. Bas1, Der, İstanbul 2014, s.12; DURAL, Mustafa / ÖZ, Turgut: Türk Özel Hukuku, Cilt: IV: Miras Hukuku, 11. Bas1, Filiz, İstanbul 2017, N.43; ANTALYA, Gökhan / SAĞLAM, İpek: Miras Hukuku, 3. Bas1, Legal, İstanbul 20015, s.38; KILIÇOĞLU, Ahmet: Miras Hukuku, 8. Bas1, Turhan, Ankara 2018, s.24; ÖZTAN, Bilge: Miras Hukuku, 6. Bas1, Turhan, Ankara 2014, s.16; SEROZAN, Rona / ENGIN, Baki İlkay: Miras Hukuku, 5. Bası, Seçkin, Ankara 2018, s.113, N.133; AYAN, Mehmet: Miras Hukuku, 9. Bas1, Seçkin, Ankara 2016, s.33; SARI, Suat: Uygulamalı Miras Hukuku, 3. Bası, Filiz, İstanbul 2016, s.19.

2 ANTALYA/SAĞLAM, s.264; SARI, 2016, s.75; TURANBOY, Kürşat Nuri: Mirasbırakanın Denkleştirme ve Tenkise Bağlı Sağlararası Hukuki İşlemleri, 1. Bası,
} 
mirasçılar, birinci zümrede mirasbırakanın altsoyudur. İkinci zümrede yalnızca mirasbırakanın ana ve babası saklı paylı mirasçıdır ${ }^{3}$. Üçüncü zümrede ise saklı paylı mirasçı yoktur. Bunların dışında, sağ kalan eş de mirasbırakanın saklı paylı mirasçısıdır. Saklı paylı mirasçılar sınırlı sayıdadır ${ }^{4}$. Bunların saklı payları da yasal miras paylarının belirli bir bölümünden ibarettir ${ }^{5}$. Saklı pay oranları, TMK md.506'da düzenlenmiştir. Buna göre, birinci zümrede mirasbırakanın altsoyunun yasal miras payının yarısı, ikinci zümrede yalnızca mirasbırakanın ana ve babasının yasal miras paylarının dörtte biri ${ }^{6}$, birinci ve ikinci zümre ile birlikte mirasçı olması halinde sağ kalan eşin yasal miras payının tamamı ve diğer hallerde sağ kalan eşin yasal miras payının dörtte üçü, mirasbırakanın üzerinde tasarrufta bulunamayacağı paylardır.

TMK md.505 f.1 hükmünde açıkça belirtildiği üzere, mirasçı olarak altsoyu, ana ve babası veya eşi bulunan mirasbırakan, mirasının saklı paylar dışında kalan kısmında ölüme bağlı tasarrufta bulunabilir. $\mathrm{Bu}$ mirasçılardan hiçbiri yoksa mirasbırakan mirasının tamamında tasarruf edebilir (TMK md.505 f.2). Saklı paylar dışında kalan ve mirasbırakanın üzerinde tasarrufta bulunabileceği bu kısma, tasarruf oranı (nisabı) veya tasarruf edilebilir kısım denir ${ }^{7}$. Mirasbırakan, tasarruf özgürlüğünün sınırları içinde, malvarlığının tamamında veya bir kısmında vasiyetname ya da miras sözleşmesiyle tasarrufta bulunabilir (TMK md.514 f.1). Görüldüğ̈̈ üzere, saklı paylı yasal mirasçılık nedeniyle Türk Medeni Hukuku'nda mirasbırakanın ölüme bağlı tasarruf yapma özgürlüğü sınırlıdır ${ }^{8}$ ve saklı paylı mirasçılar, mirasbırakanın tasarruflarına karşı korunurlar ${ }^{9}$. Saklı paylarının karşılığını alamayan mirasçılar,

Yetkin, Ankara 2010, s.45; ÇAĞA, Tahir: Türk-İsviçre Hukukuna Göre Mahfuz Hisseli Mirasçıların Hukuki Vaziyeti, 1. Bası, İsmail Akgün Matbaası, İstanbul 1950, s.3.

3 İkinci zümrede kardeşlerin saklı payı, 4.5.2007 tarihli ve 5650 sayılı Türk Medeni Kanunu'nda Değişiklik Yapılmasına Dair Kanun ile kaldırılmıştır. Bu kanun, 26518 sayılı ve 10 Mayıs 2007 tarihli Resmi Gazete'de yayınlanmıştır.

${ }^{4}$ Mirasbırakanın saklı paylı mirasçıları belirleme yetkisi yoktur. Saklı paylı mirasçılar, kanun koyucu tarafindan belirlenir (TURANBOY, s.46).

${ }^{5}$ ANTALYA/SAĞLAM, s.265; SARI, 2016, s.75; IMRE/ERMAN, s.231.

${ }^{6}$ İkinci zümrede kardeşlerin saklı payı, 4.5.2007 tarihli ve 5650 sayılı Türk Medeni Kanunu'nda Değişiklik Yapılmasına Dair Kanun ile kaldırılmıştır. Bu kanun, 26518 sayılı ve 10 Mayıs 2007 tarihli Resmi Gazete'de yayınlanmıştır.

7 TURANBOY, s.45-46; DURAL/ÖZ, N.1040; İMRE/ERMAN, s.231; SARI, 2016, s.77; ANTALYA/SAĞLAM, s.264.

${ }^{8}$ İMRE/ERMAN, s.231; DURAL/ÖZ, N.1038.

${ }^{9}$ DURAL/ÖZ, N.1038. 
mirasbırakanın tasarruf oranını (nisabını) aşan tasarruflarının tenkisini dava edebilirler (TMK md.560 f.1). Buna göre tenkis, saklı pay ihlalinin yaptırımıdır ${ }^{10}$.

TMK md.202 f.2 hükmü uyarınca, "Eşler arasında edinilmiş mallara katılma rejiminin uygulanması asıldır". Bu hükümle edinilmiş mallara katılma rejimi ${ }^{11}$, yasal mal rejimi olarak kabul edilmiştir. TMK md.236 f.1 hükmü uyarınca, "Her eş veya mirasçıları, diğer eşe ait artık değerin yarlsı üzerinde hak sahibi olurlar". Buna karş1lık, TMK md.237 f.1 hükmü uyarınca, "Artık değere katılmada mal rejimi sözleşmesiyle başka bir esas kabul edilebilir". Örneğin evlilik birliğinin eşlerden birinin ölümüyle sona ermesi halinde ${ }^{12}$, edinilmiş mallara katılma rejiminin tasfiyesinde sağ kalan eşin, diğer eşe ait artık değerin 3/4' ü veya tamamı üzerinde hak sahibi olacağına ilişkin bir mal rejimi sözleşmesi yapılabilir.

${ }^{10}$ İMRE/ERMAN, s.261.

11 Edinilmiş mallara katılma rejimi hakkında detaylı bilgi için bkz. ZEYTiN, Zafer: Edinilmiş Mallara Katılma Rejimi ve Tasfiyesi, 3. Bası, Seçkin, Ankara 2017; SARI, Suat: Evlilik Birliğinde Yasal Mal Rejimi Olarak Edinilmiş Mallara Katılma Rejimi, 1. Bas1, Beşir, İstanbul 2007; ŞIPKA, Şükran: Türk Hukukunda Edinilmiş Mallara Katılma Rejimi ve Uygulamaya İlişkin Sorunlar, 3. Bası, On İki Levha, İstanbul 2013; KILIÇOĞLU, Ahmet: Edinilmiş Mallara Katılma Rejimi, 2. Bası, Turhan, Ankara 2002; KILIÇOĞLU, Ahmet: Katkı-Katılma Alacağı, 4. Bası, Turhan, Ankara 2014; ATEŞ, Turan: Edinilmiş Mallara Katılma Rejimi, 3. Bası, Bilge, Ankara 2013; ÖZUĞUR, Ali İhsan: Mal Rejimleri, 1. Bası, Seçkin, Ankara 2004; YAĞCIOĞLU, Ali Haydar: Edinilmiş Mallara Katılma Rejiminde Eşlerin Yasal Alım Hakkı, 1. Bası, Güncel Hukuk, İzmir 2007; KIRMIZI, Mustafa: Açıklamalı-İçtihatlı Edinilmiş Mallara Katılma Rejimi ve Aile Konutu, 3. Bası, Ankara 2014; UZUN, Neşe: Edinilmiş Mallara Katılma Rejiminin Diğer Mal Rejimleriyle Karşılaştırılması, Yayınlanmamış Yüksek Lisans Tezi, İstanbul, Bahçeşehir Üniversitesi Sosyal Bilimler Enstitüsü, 2009; YAZGAN, Selda: Edinilmiş Mallara Katılma Rejiminde Mal Paylaşımı, Yayınlanmamış Yüksek Lisans Tezi, Ankara, Gazi Üniversitesi Sosyal Bilimler Enstitüsü, 2014; DURAL, Mustafa/ ÖĞÜZ, Tufan/ GÜMÜŞ, Mustafa Alper: Türk Özel Hukuku, Cilt: III: Aile Hukuku, 13. Bas1, Filiz, İstanbul 2018, N.1066 vd.; YILDIRIM, Abdülkerim: Türk Aile Hukuku, 1. Bası, Savaş, Ankara 2014, s.99 vd.; KILIÇOĞLU, Ahmet: Aile Hukuku, 3. Bas1, Turhan, Ankara 2017, s.270 vd.; KÖSEOĞLU, Bilal/KOCAAĞA, Köksal: Aile Hukuku ve Uygulamas1, 2. Bas1, Ekin, Bursa 2011, s.643 vd.; ÖZTAN, Bilge: Aile Hukuku, 6. Bası, Turhan, Ankara 2015, s.435 vd.; HATEMİ, Hüseyin/KALKAN OĞUZTÜRK, Burcu: Aile Hukuku, 2. Bası, Vedat, İstanbul 2013, s.89 vd;; AKINTÜRK, Turgut/ATEŞ, Derya: Aile Hukuku, Beta, 20. Bası, İstanbul 2017, s.154 vd.; ERDEM, Mehmet: Aile Hukuku, 1. Bası, Seçkin, Ankara 2018, s.267 vd.

12 Önemle belirtmek gerekir ki doktrindeki baskın görüşe göre, eşlerden birinin gaipliği halinde, gaiplik kararının kesinleşmesiyle, ölüm tehlikesinin gerçekleştiği veya hakkında gaiplik kararı verilen kişiden son haberin alındığı tarihten itibaren, edinilmiş mallara katılma rejimi kendiliğinden sona ermiş olur (ZEYTIN, s.108; DURAL/ÖĞÜZ/GÜMÜŞ, N.1113; ERDEM, s.281). 
$\mathrm{Bu}$ şekilde să̆ kalan eş lehine yapılan anlaşmalar, ölen eşin yani mirasbırakanın tereke mevcudunu azaltacağı için, saklı paylı mirasçıların saklı payını ihlal edebilir ${ }^{13}$. Önemle belirtmek gerekir ki evlilik birliğinin eşlerden birinin ölümüyle sona ermesi halinde, sağ kalan eşin, artık değerin tamamı üzerinde hak sahibi olacağına ilişkin bir mal rejimi sözleşmesi yapılmışsa ve ölen eşin terekesinin aktifi edinilmiş mallardan oluşuyorsa böyle bir durumda, sağ kalan eş dışındaki mirasçıların ölen eşin mirasından hiçbir şey alamaması ihtimali ortaya çıkar ${ }^{14}$. Bu noktada TMK md.237 f.2 hükmü devreye girer. TMK md.237 f.2 hükmü uyarınca, "Bu tür anlaşmalar, eşlerin ortak olmayan çocuklarının ve onların altsoylarının sakl paylarını zedeleyemez". Başka bir deyişle miras hukuku hükümleri uyarınca söz konusu olan saklı paylı mirasçılık korumasından, yalnızca eşlerin ortak olmayan çocukları ve bunların altsoyları yararlanır. Buna karşılık eşlerin ortak çocukları ile bunların altsoyları ve ikinci zümrede yer alan saklı paylı mirasçıları yani ölen eşin ana ve babası, miras hukuku hükümleri ile kendilerine bahşedilen saklı paylı mirasçılık korumasından yararlanamazlar ${ }^{15}$.

Benzer bir düzenleme, seçimlik mal rejimlerinden mal ortaklığ bakımından da söz konusudur. Şöyle ki TMK md.276 hükmü uyarınca, "Eşlerden birinin ölümü veya diğer bir mal rejiminin kabulü sebebiyle mal ortaklı̆̆ının sona ermesi hâlinde, her eşe veya mirasçılarına ortaklık mallarının yarısı verilir. Mal rejimi sözleşmesiyle başka bir paylaşma oranı kararlaştırılabilir. Bu tür anlaşmalar altsoyun sakl payların zedeleyemez”. Buna göre, miras hukuku hükümleri uyarınca söz konusu olan saklı paylı mirasçılık korumasından, yalnızca ölen eşin altsoyu yani birinci zümrede yer alan saklı paylı mirasçıları yararlanır. Buna karşılık ölen eşin ikinci zümrede yer alan saklı paylı mirasçıları yani ana ve babası, miras hukuku hükümleri ile kendilerine bahşedilen saklı paylı mirasçlık korumasından yararlanamaz ${ }^{16}$. Oysa miras hukuku sistemimizde, yalnızca mirastan feragat, mirasçılıktan çıkarma ve

${ }^{13}$ ŞENOCAK, Zarife: "Edinilmiş Mallara Katılma Rejiminde Artık Değere Katılma İle İlgili Mal Rejimi Sözleşmeleri ve Tenkisi”, Ankara Üniversitesi Hukuk Fakültesi Dergisi, C.58, S.2, 2009, s.379.

${ }^{14}$ ŞENOCAK, 2009, s.379.

${ }^{15}$ ACAR, Faruk: Aile Hukukumuzda Aile Konutu, Mal Rejimleri, Eşin Yasal Miras Payı, 5. Bası, Seçkin, Ankara 2016, s.126; ŞIPKA, s.278-279; ŞENOCAK, 2009, s.396; ÖZUĞUR, 2004, s.51; ZEYTIN, s.320; SARI, 2007, s.241.

16 İMRE/ERMAN, s.237; ARBEK, Ömer: Miras Hukukunda Ölüme Bağlı İşlemlerde İrade Serbestisi Sinırları ve Müeyyidesi, 1. Bası, Yetkin, Ankara 2013, s.50. 
mirastan yoksunluk gibi istisnai hallerde, saklı paylı yasal mirasçıların saklı payları, mirasbırakan tarafindan ihlal edilebilir ${ }^{17}$.

Bazı yazarlara göre ${ }^{18}$, miras hukuku, "buyruklar, yasaklar ve sinırlamalar hukukudur". Örneğin ölüme bağlı tasarruflar yalnızca vasiyetname $^{19}$ veya miras sözleşmesi şeklinde yapılabilir. Zira şekli anlamda ölüme bağlı tasarruflar bakımından sınırlı sayı ilkesi geçerlidir. Bunun yanı sıra, vasiyetname ve miras sözleşmesi, sıkı şekil şartlarına tabidir; öngörülen şekilde yapılmamaları halinde geçersiz olurlar ${ }^{20}$. Buna karşılık, mal rejimi sözleşmeleriyle eşlerin ölüme bağlı tasarrufta bulunmaları hatta yukarıda belirtilen hükümler (TMK md.237 f.2 ve TMK md.276 f.3) uyarınca, bazı yasal mirasçılarının saklı paylarını ihlal edebilmeleri mümkündür. Bunun yanı sıra, TMK md.237 f.2 hükmünde, ortak altsoy ve ortak olmayan altsoy şeklinde bir ayırım yapılmaktadır. Böylelikle mirasbırakanın birinci zümre yasal mirasçıları arasındaki eşitlik bozulmaktadır. Oysa TMK md.669 f.1 hükmü uyarınca, "Yasal mirasçılar, mirasbırakandan, miras paylarına mahsuben elde ettikleri sağlararası karşılıksız kazandırmaları, denkleştirmeyi sağlamak için terekeye geri vermekle birbirlerine karşı yükümlüdürler”. Denkleştirmenin amacı ise mirasçılar arasında eşitliğin sağlanmasıdır ${ }^{21}$. Görüldüğü üzere, mal rejimlerine ilişkin TMK md.237 f.2 ve TMK md.276 f.3 hükümleri, miras hukuku sistemimizle uyum içinde değildir.

Bu çalışmada, TMK md.237 f.2 ve TMK md.276 f.3 hükümlerinin, miras hukuku sistemimiz karşısındaki durumu çeşitli yönlerden incelenmiş ve kanun koyucunun amacı ile miras hukukunun ilkeleri dikkate alınarak, bazı değişiklik önerilerinde bulunulmuştur.

\footnotetext{
${ }^{17}$ TURANBOY, s.45.

${ }^{18}$ SEROZAN/ENGIN, s.67, N.45.

${ }^{19}$ Miras hukukumuzda vasiyetnamenin üç türü bulunur. Bunlar; el yazılı vasiyetname, resmi vasiyetname ve sözlü vasiyetnamedir. Detaylı bilgi için bkz. GÖNEN, Doruk: El Yazıl1 Vasiyetname, 1. Bas1, Legal, İstanbul 2007; SANBERK, Mustafa Turgut: Resmi Vasiyetname, Yayınlanmamış Yüksek Lisans Tezi, İstanbul, Marmara Üniversitesi Sosyal Bilimler Enstitüsü, 2002; KOYUNCU, Ferhat: Sözlü Vasiyetname, 1. Bas1, Seçkin, Ankara 2014.

${ }^{20}$ TMK md.557 b.4 uyarınca, ölüme bağlı tasarruf kanunda öngörülen şekillere uyulmadan yapılmışsa ölüme bağlı tasarrufun iptali için dava açılabilir. Detaylı bilgi için bkz. TURAN, Gamze: Ölüme Bağlı Tasarrufların Hükümsüzlüğü, 1. Bası, Turhan, Ankara 2009.

${ }^{21}$ TURAN BAŞARA, Gamze: Miras Hukukunda Denkleştirme, 1. Bası, Turhan, Ankara 2013, s.19-20; TURANBOY, s.29; İMRE/ERMAN, s.512; KILIÇOĞLU, 2018, s.469; AYAN， s.309; SEROZAN/ENGIN， s.586，N.39a; ANTALYA/SAĞLAM， s.451; ÖZTAN, 2014, s.506.
} 


\section{MAL REJIMI SÖZLEŞMELERINIIN HUKUKİ NITELIIĞİ: SAĞLARARASI KAZANDIRMA MI YOKSA ÖLÜME BAĞLI TASARRUF MU?}

Mal rejimi sözleşmelerinin sağlararası kazandırma mı yoksa ölüme bağlı tasarruf mu olduğu tartışmalıdır ${ }^{22}$. Konuya ilişkin çeşitli görüşler söz konusudur. Bir görüşe göre ${ }^{23}$, artık değere katılma anlaşmaları, tamamen sağ kalan eş lehine yapılmış olsa dahi mal rejimi hukukuna özgü sağlararası bir hukuki işlem olarak ele alınmalıdır. Zira artık değere katılma anlaşmaları; şekil, ehliyet ve sona erme bakımından özel hükümlere tabi tutulmuştur. Başka bir görüşe göre ${ }^{24}$, bu anlaşmalar her ne kadar eşlerin sağlığında yapılıyor olsa da, hüküm ve sonuçları eşlerden birinin ölümü halinde meydana geldiğinden, ölüme bağlı tasarruf niteliğinde kabul edilmelidir. Bir diğer görüş ${ }^{25}$ ise, artık değere katılma anlaşmalarının ölüme bağlı tasarruf ya da sağlararası kazandırma niteliğinde olabileceği yönündedir. Bu görüşe göre, eğer yapılan anlaşma, TMK md. 237 hükmü kapsamında bir anlaşma ise ölüme bağlı tasarruf niteliğindedir; buna karşılık yapılan anlaşma, TMK md. 238 hükmü kapsamında bir anlaşma ise sağlararası bir kazandırma niteliğinde olacaktır.

Konuya ilişkin belli başlı görüşler, yukarıda ifade edildiği gibidir. Bu noktada önemle belirtmek gerekir ki TMK md. 238 hükmü uyarınca, "Mahkemece evliliğin iptal veya boşanma sebebiyle sona erdirilmesine veya mal ayrillğına geçilmesine karar verilmesi hallerinde, kanundaki artık değere katılmaya ilişskin düzenlemeden farklı anlaşmalar, ancak mal rejimi sözleşmesinde bunun açıç̧a öngörülmüş olması halinde geçerlidir". Buradan hareketle, hangi hallerde uygulanacağı belirtilmeden yapılan artık değere katılma anlaşmalarının, yalnızca eşlerden birinin ölümü halinde yani evlilik birliğinin ölümle sona ermesi halinde hüküm ifade edeceği sonucuna ulaşılmaktadır ${ }^{26}$. O halde, TMK md.237 hükmü kapsamında yapılan mal rejimi sözleşmeleri, ölüme bağlı tasarruf

\footnotetext{
22 İsviçre doktrinindeki tartışmalar hakkında detaylı bilgi için bkz. ŞENOCAK, 2009, s.398 vd.

${ }^{23}$ ŞENOCAK, 2009, s.402.

${ }^{24}$ ACAR, s.129.

${ }^{25}$ ŞIPKA, s.281.

${ }^{26}$ ŞIPKA, s.281; ACAR, s.121; ŞENOCAK, 2009, s.389; ZEYTIN, s.318; SARI, 2007, s.243.
} 
niteliğindedir ${ }^{27}$. Bu durum, şüphesiz şekli anlamda ölüme bağl1 tasarruflara hâkim olan sınırlı sayı ilkesi bakımından sorunludur.

Üzerinde durulması gereken önemli bir diğer konu, ölüme bağl1 tasarruf ehliyetidir. TMK md.502 hükmü uyarınca, "Vasiyet yapabilmek için ayırt etme gücüne sahip ve onbeş yaşını doldurmuş olmak gerekir". Buna göre, on beş yaşını doldurmuş olan küçükler ve kısıtlılar, ayırt etme gücüne sahip olmak şartıyla vasiyetname yapabilirler ${ }^{28}$. Öte yandan, TMK md.503 hükmü uyarınca, "Miras sözleşmesi yapabilmek için ayırt etme gücüne sahip ve ergin olmak, klsitl bulunmamak gerekir". Başka bir deyişle, miras sözleşmesi yapabilmek için tam fiil ehliyeti gerekir. Buna göre, ayırt etme gücüne sahip olan kısıtlllar ve küçükler, miras sözleşmesi yaparak ölüme bağlı tasarrufta bulunamazlar ${ }^{29}$. Buna karş1lı, TMK md.204 hükmü uyarınca, ayırt etme gücüne sahip olan kısıtlılar ve küçükler, yasal temsilcilerinin rızasıyla mal rejimi sözleşmesi yapabilirler $^{30}$. Yani miras sözleşmesiyle ölüme bağl1 tasarrufta bulunamayan ayırt etme gücüne sahip kısıtlılar ve küçükler, mal rejimi sözleşmeleriyle ölüme bağlı tasarrufta bulunabilirler ${ }^{31}$. Bu durum da ölüme bağlı tasarruf ehliyeti bakımından çelişkili bir durumdur.

${ }^{27}$ MK md.237 hükmü kapsamında yapılan mal rejimi sözleşmelerinin ölüme bağlı tasarruf niteliğinde olduğu dikkate alındığında, mirasçılıktan çıkarma ve mirastan yoksunluk sebeplerine dayanılarak, bu sözleşmelerden dönülebileceği kabul edilmektedir (SARI, 2007, s.232; ZEYTIN, s.325; ŞIPKA, s.281).

${ }^{28}$ Ehliyetsizlik, TMK md.557 b.1 hükmü uyarınca, ölüme bağlı tasarruf bakımından bir iptal sebebidir. Bu noktada belirtmek gerekir ki vasiyetçinin hangi sebeple kısıtlandığı önemlidir. Ĕger vasiyetçi, akıl hastalığı veya akıl zayıflığı sebebiyle kısıtlanmış ise bu durumda karine olarak vasiyetçinin vasiyetname yaptığ 1 anda ayırt etme gücüne sahip olmadığı kabul edilir. Böyle bir durumda vasiyetnamenin yapıldığı esnada vasiyetçinin ayırt etme gücüne sahip olduğunun ispat edilmesi gerekir. Buna karşllık eğer vasiyetçi, başka bir sebeple kısıtlanmış ise bu durumda karine olarak vasiyetçinin vasiyetname yaptığı anda ayırt etme gücüne sahip olduğu kabul edilir. Böyle bir durumda ise vasiyetnamenin yapıldığı sırada vasiyetçinin ayırt etme gücüne sahip olmadığının ispat edilmesi gerekir. IMRE /ERMAN, s.65-66.

${ }^{29}$ Bir miras sözleşmesinde, her iki taraf ölüme bağlı tasarrufta bulunabileceği gibi, yalnızca taraflardan biri de ölüme bağlı tasarrufta bulunabilir. Miras sözleşmesinin ölüme bağlı tasarrufta bulunmayan tarafı bakımından genel ehliyet kuralları uygulanır. Eğer yapılan işlem tek taraflı ivazsız bir miras sözleşmesi ise ayırt etme gücüne sahip küçük veya kısıtlı, bu işlemi tek başına yapabilir. Buna karşılık yapılan işlem tek taraflı ancak ivazlı bir miras sözleşmesi ise ayırt etme gücüne sahip küçük veya kısıtlı yasal temsilcisinin izniyle bu işlemi yapabilir. Ayrıca TMK md.463 b.5 hükmü uyarınca, miras sözleşmeleri bakımından vesayet makamının izninden sonra denetim makamının da izni gereklidir. Bkz. İMRE/ERMAN, s.189; DURAL/ÖZ, N.290-293.

${ }^{30}$ KILIÇOĞLU, 2014, s.81.

${ }^{31}$ ŞENOCAK, 2009, s.402. 


\section{MIRAS HAKKININ HUKUKİ NITELIIĞi}

Miras hakkı, mirasın açılması yani mirasbırakanın ölümü ile doğar. Mirasbırakanın ölümüne kadar, bir miras hakkından bahsedilemez ancak beklenen bir hak söz konusudur ${ }^{32}$. Bazı yazarlara göre ${ }^{33}$, miras hakk1 beklenen hak olarak kabul edilemez. Zira mirasçılar, mirasbırakanın ölümünden önce esasen mirasçılık sıfatı taşımadıkları gibi mirasbırakanın muhtemel terekesi üzerinde de hak sahibi değildir. Oysa beklenen haktan bahsedebilmek için bekleme durumunun hakkın kazanılması aşamasında hukuk düzeni tarafindan korunuyor olması gerekir ${ }^{34}$. Bu duruma örnek olarak, mirasbırakanın ölümünden önce muhtemel mirasçıların tespit, tenkis ve iptal davası açamaması ve miras payının alacaklılar tarafından haczedilememesi gösterilmektedir ${ }^{35}$.

Önemle belirtmek gerekir ki muhtemel miras hakkının, mirasbırakanın ölümünden önce hukuk düzeni tarafindan tam olarak korunamaması, eşyanın doğasından kaynaklanır. Zira kimin önce öleceği belli değildir. Bu yönüyle mirasbırakan ve mirasçı1ık sıfatı tesadüfîdir. Örneğin ana, baba ve ortak çocuktan oluşan bir ailede, önce ananın ölmesi halinde, mirasbırakan sıfatı anaya, mirasçı sıfatı ise baba (1/4) ve çocuğa (3/4) ait olur; önce babanın ölmesi halinde, mirasbırakan sıfatı babaya, mirasçı sıfatı ise ana (1/4) ve çocuğa (3/4) ait olur. Buna karşılık, önce çocuğun ölmesi halinde mirasbırakan sıfatı çocuğa, mirasçılık sıfatı ise ana $(1 / 2)$ ve babaya $(1 / 2)$ ait olur. İşte, muhtemel miras hakkının, mirasbırakanın ölümünden önce tam olarak korunamaması miras hukuku bakımından kimin hangi sıfatı taşıyacağının belli olmamasından ileri gelir.

Muhtemel miras hakkı, tamamen korunmasız bırakılmış bir hak değildir ${ }^{36}$. Öncelikle, muhtemel miras payının korunmasına yönelik olarak, delil tespiti talebinde bulunmanın mümkün olduğu kabul edilmektedir ${ }^{37}$. Bu konuya ilişkin olarak Akkanat şöyle bir örnek vermektedir:

${ }^{32}$ DURAL/ÖZ, N.880; ALBAŞ, Hakan: "Mirastan Feragat Sözleşmesi ve Hükümlerine İlişkin Bazı Sorunlar", Prof. Dr. Ünal Narmanlığlu'na Armağan, Dokuz Eylül Üniversitesi Hukuk Fakültesi Dergisi, C.9, S.Özel, 2007, s.535, 540, 541, 543, 546.

${ }^{33}$ SEROZAN/ENGIN, s.36, N.6; ANTALYA/SAĞLAM, s.49-50; AKKANAT, Halil: Ölümün Özel Hukuk İlişkilerine Etkisi, 1. Bası, Filiz, İstanbul 2004, s.6.

${ }^{34}$ Bu konu hakkında detaylı bilgi için bkz. ANTALYA/SAĞLAM, s.45 vd.

${ }^{35}$ ANTALYA/SAĞLAM, s.52; SEROZAN/ENGIN, s.36, N.6.

${ }^{36}$ Muhtemel mirasçıların menfaatlerini korumaya yönelik işlemler hakkında detaylı bilgi için bkz. AKKANAT, Özel Hukuk, s.7 vd.

${ }^{37}$ AKKANAT, Özel Hukuk, s.7. 
"Kendisinde akıl hastalı̆̆ belirtileri görülmeye başlanmış bir mirasbırakan, hastalığının başlangıç döneminde bir ölüme bağll tasarruf yapmış ya da yapmak üzeredir. Ĕger bu dönemde bir doktor muayenesi söz konusu olmamış ise, daha sonraki bir zaman diliminde, bu ölüme bağll tasarrufun geçerliliği ile ilgili olarak açılacak bir davada, mirasbırakanın ölüme bağlı tasarruf yapma ehliyetine sahip olup olmadığının ispatı ya imkânsız olacak veya çok büyük güçlük arz edecektir. Bu sebeple muhtemel mirasçı bakımından, mirasbirakanın söz konusu ölüme bağll tasarrufun yapıldiğl dönemdeki zihni durumun tespiti büyük bir önem taşlyacaktır $^{38, "}$

Mirastan feragat sözleşmesi de muhtemel miras hakkının hukuk sistemi tarafından korunmasına örnek olarak gösterilebilir. Zira mirasçının rızası olmaksızın, mirasbırakan mirasçının saklı payı üzerinde tek başına tasarrufta bulunamaz; onu saklı payından mahrum edemez.

Mirasbırakanın sağlığında, muhtemel mirasçılar tarafından, miras hakkının belirlenmesine ilişkin bir tespit davası veya bir iptal davası açılamasa da mirastan feragat sözleşmesinin tarafı olan muhtemel mirasçının, mirasbırakanın sağlığında, bu sözleşmenin geçersizliğini ileri sürebileceği ve geçersizlik durumunun tespitine ilişkin bir dava açabileceğ ${ }^{39}$; mirasbırakanın ise bu sözleşmenin geçerliliğinin tespitini mahkemeden talep edebileceğ $i^{40}$ de kabul edilmektedir. Bu durum yalnızca mirastan feragat sözleşmeleri bakımından geçerli değildir. Miras sözleşmelerinin şekle aykırılık veya ehliyetsizlik nedeniyle hükümsüz olduğunun taraflarca, mirasbırakanın sağlı̆̆ında ileri sürülebileceği belirtilmektedir $^{41}$.

Muhtemel miras hakk1, her ne kadar haczedilemez olsa da üzerinde hiçbir tasarrufta bulunulamayan bir hak değildir. Zira TMK md.678 f.1 hükmü uyarınca, bir mirasçı mirasbırakanın katılmasıyla veya izniyle, mirasın açılmasından önce de miras payını diğer mirasçılara veya üçüncü bir kişiye devredebilir ${ }^{42}$. Böyle bir durumda, muhtemel miras payını

\footnotetext{
${ }^{38}$ AKKANAT, Özel Hukuk, s.8.

${ }^{39}$ AKKANAT, Özel Hukuk, s.10.

${ }^{40}$ AKKANAT, Özel Hukuk, s.13.

${ }^{41}$ İMRE/ERMAN, s.193-194.

42 Detaylı bilgi için bkz. SAPANOĞLU, Süleyman: Miras Paylaşma ve Miras Payının Devri Sözleşmeleri, 1. Bası, Yetkin, Ankara 2011, s.248 vd. Mirasın açılmasından önce yapılan miras payının devri sözleşmesinin, mirasın açılmasından sonra yapılan miras payının devri sözleşmesi ile karşılaştırılması hakkında bkz. GENÇ ARIDEMİ, Arzu:
} 
devreden mirasçı, mirasçılık sıfatını kaybetmez; muhtemel miras payını devralan da mirasçılık sıfatını kazanmaz yalnızca bir talep hakkı elde eder ${ }^{43}$. TMK md.648 hükmü uyarınca, "Açılmış mirasta bir mirasçının payını devralmış veya haczettirmiş olan ya da elinde mirasçıya karşı alınmış borç ödemeden aciz belgesi bulunan alacaklı, sulh hâkiminden bu mirasçının yerine paylaşmaya katılmak üzere bir kayyım atanmasını isteyebilir". Bu hüküm, mirasın açılmasından sonra yapılan pay devri sözleşmelerine ilişkindir. Zira mirasçıların alacaklıları, alacak haklarını, paylaşma sonucunda mirasçıya isabet eden malvarlığı değerleri üzerinden alacakları için, paylaşmanın nasıl yapılacağı mirasçıların alacaklılarını yakından ilgilendiren bir konudur ${ }^{44}$. Bu hükmün, kıyasen mirasın açılmasından önce yapılan pay devri sözleşmeleri bakımından da uygulanabileceği kabul edilmektedir ${ }^{45}$. Buna göre, mirasın açılmasından önce mirasçının muhtemel miras payını devralan alacaklı da paylaşmaya katılmak üzere kayyım atanmasını talep edebilir. Bunun yanı sıra, mirasın açılmasından önce yapılan miras payının devri sözleşmelerinin geçerliliğine veya geçersizliğine ilişkin bir tespit davasının, mirasbırakanın ölümünden önce de açılabileceği kabul edilmektedir ${ }^{46}$.

Son olarak, mirasbirakanın kisitlanması da dolaylı olarak muhtemel mirasçıların beklenen miras haklarını koruyucu etkili sonuçlar doğurur ${ }^{47}$. Mirasbırakanın TMK md.405 veya TMK md.406 hükümleri uyarınca kısıtlanması halinde durum böyledir. TMK md.405 hükmü uyarınca, "Akıl hastalı̆̆ veya akıl zayıflı̆g sebebiyle işlerini göremeyen veya korunması ve bakımı için kendisine sürekli yardım gereken ya da başkalarının güvenliğini tehlikeye sokan her ergin klsitlanır". Bunun yanı sıra, TMK md.406 hükmü uyarınca, "Savurganlığı, alkol veya uyuşturucu madde bağımlılı̆̆ı, kötü yaşama tarzl veya malvarlığını kötü yönetmesi sebebiyle kendisini veya ailesini darlık veya yoksulluğa düşürme tehlikesine yol açan ve bu yüzden devaml korunmaya ve bakıma muhtaç olan ya da başkalarının güvenliğini tehdit eden her ergin kisitlanır". Kısıtlılar ise

Mirasın Açılmasından Sonra Yapılan Miras Payının Devri Sözleşmesi, 1. Bası, On İki Levha, İstanbul 2012, s.112 vd.

${ }^{43}$ KOCAYUSUFPAŞAOĞLU, Necip: Miras Hukuku, 3. Bası, Filiz, İstanbul 1987, s.547; IMRE/ERMAN, s.557.

${ }^{44}$ BAYGIN, Cem: Türk Miras Hukukunda Alacaklıların Korunması, 1. Bası, Seçkin, Ankara 2005, s.182.

${ }^{45}$ KOCAYUSUFPAŞAOĞLU, s.548; İMRE/ERMAN, s.558.

${ }^{46}$ AKKANAT, Özel Hukuk, s.12.

${ }^{47}$ AKKANAT, Özel Hukuk, s.16-17; ANTALYA/SAĞLAM, s.52. 
ayırt etme gücüne sahip olsalar dahi yasal temsilcilerinin rızası olmadıkça kendi işlemleriyle borç altına giremezler (TMK md.16). Hatta bazı işlemler bakımından yasal temsilcinin rızası yeterli değildir; vesayet organlarının izni de gereklidir (TMK md.462 ve md.463). Böylelikle kısıtlanan kişinin malvarlığı korunur. Kısıtlının malvarlığının korunması ise tereke değerlerinin yani muhtemel mirasçıların beklenen miras haklarının korunması anlamına gelir ${ }^{48}$.

Miras hakkının, beklenen hak niteliğinde olduğu; mirastan feragat sözleşmesi yapılmadan, mirasbırakanın mirasçısının saklı payı üzerinde tasarrufta bulunamadığı; mirasbırakanın katılımı veya izniyle mirasçının muhtemel miras payı üzerinde tasarruf edebilmesinin mümkün olduğu; miras sözleşmelerinin geçersizliğinin mirasbırakanın ölümünden önce de ileri sürülebildiği; delil tespiti ve bazı şartların gerçekleşmesi halinde mirasbirakanın kisitlanmasını talep etme gibi yollarla muhtemel miras hakkının korunabildiği dikkate alındığında, bu hakkın, artık değere (TMK md.237 f.2) ve ortaklık mallarına (TMK md.276 f.3) katılma anlaşmalarıyla tamamen mirasbırakanın ve eşinin tasarrufuna terk edilmiş olması, yine çelişkili bir durum olarak karşımıza çıkmaktadır.

\section{MİRASBIRAKANIN TASARRUF ÖZGÜRLÜĞÜNÜN SINIRI}

\section{A. Genel Olarak}

Saklı paylı yasal mirasçılık nedeniyle Türk Medeni Hukuku'nda mirasbırakanın ölüme bağlı tasarruf yapma özgürlüğü sınırlıdır ${ }^{49}$. Böylelikle saklı paylı yasal mirasçılar, mirasbırakanın tasarruflarına karşı korunurlar $^{50}$. Saklı paylarının karşılı̆̆ını alamayan mirasçılar, mirasbırakanın tasarruf oranını (nisabını) aşan tasarruflarının tenkisini dava edebilirler (TMK md.560 f.1). Buna göre tenkis, saklı pay ihlalinin yaptırımıdır ${ }^{51}$. Miras hukuku sistemimizde, yalnızca mirastan feragat, mirasçılıktan çıkarma ve mirastan yoksunluk $^{52}$ gibi istisnai hallerde,

\footnotetext{
${ }^{48}$ ANTALYA/SAĞLAM, s.52.

${ }^{49}$ ÇAĞA, s.3, 63; IMMR/ERMAN, s.231; DURAL/ÖZ, N.1038.

${ }^{50}$ DURAL/ÖZ, N.1038.

${ }^{51}$ KOCAYUSUFPAŞAOĞLU, s.360; İMRE/ERMAN, s.261.

52 Mirastan yoksunluk halinde, mirasbırakanın tasarruf oranının nasıl hesaplanacağı tartışmalıdır. Bir görüşe göre, mirastan yoksunluk halinde mirasbırakanın tasarruf oranı, mirasçılıktan çıkarmada olduğu gibi hesaplanır. Zira mirastan yoksunluk, mirasçılıktan çıkarılmanın tamamlayıcısıdır. Bkz. IMRE/ERMAN, s.313. Buna karşılık, bir başka görüşe göre, mirastan yoksunluk halinde mirasbırakanın tasarruf oranı, mirasın reddinde olduğu gibi hesaplanır. Bkz. SARI, 2016, s.90; ANTALYA/SAĞLAM, s.289.
} 
mirasbırakanın tasarruf oranı (nisabı) genişler ${ }^{53}$. Önemle belirtmek gerekir ki bu hallerde de mirasbırakanın tasarruf oranının genişlemesi mutlak değildir. Aşağıda sırasıyla mirasçılıktan çıkarma, mirastan feragat ve mirastan yoksunluk hallerinin mirasbirakanın tasarruf oranı (nisabı) üzerindeki etkileri incelenmiştir.

\section{B. Mirasbırakanın Tasarruf Özgürlüğünün Genişlemesi 1. Mirasçılıktan Çıkarma Halinde}

TMK md.510 hükmü uyarınca; mirasçı, mirasbırakana veya mirasbırakanın yakınlarından birine karşı ağır bir suç işlemişse ya da mirasçı, mirasbırakana veya mirasbırakanın ailesi üyelerine karşı aile hukukundan doğan yükümlülüklerini önemli ölçüde yerine getirmemişse $^{54}$, mirasbırakan ölüme bağlı tasarrufla saklı paylı mirasçısını mirasçılıktan çıkarabilir. Buna cezai mirasçılıktan çıkarma ${ }^{55}$ denir. Cezai mirasçl1ıktan çıkarma, aile bağına layık olmadı̆̆ını gösteren kimseye uygulanan bir medeni hukuk yaptırımı olarak tanımlanmaktadır ${ }^{56}$. Buna

${ }^{53}$ Benzer bir değerlendirme için bkz. TURANBOY, s.45.

${ }^{54}$ Yarg. 2. HD., 30.9.1971, 5309/5424 (http://www.kazanci.com, 21 Mart 2017); Yarg. 2. HD., 30.3.1976, 2467/2802 (http://www.kazanci.com, 21 Mart 2017); Yarg. 2. HD., 4.2.2002, 194/1169 (http://www.kazanci.com, 21 Mart 2017).

${ }^{55}$ Detaylı bilgi için bkz. YAĞCI, Kürşad: Cezai Mirasçılıktan Çıkarma, 1. Bası, On İki Levha, İstanbul 2013; ÇUBUKGIL, Rıza: "Mirastan Adi Iskatın Hukuki Mahiyeti ve Sebepleri”, Ankara Üniversitesi Hukuk Fakültesi Dergisi, C.7, S.3-4, 1950, ss.441-467; ÇUBUKGILL, Rıza: "Medeni Kanunumuzda Mirastan Adi Iskatın Hüküm ve Neticeleri, Ankara Üniversitesi Hukuk Fakültesi Dergisi, C.8, S.3-4, 1951, ss.595-609; SEZEN, Cehdi Cihan: Türk Hukukunda Mirastan Çıkarma, Yayınlanmamış Yüksek Lisans Tezi, İstanbul, Marmara Üniversitesi Sosyal Bilimler Enstitüsü, 2008; KARACA, Beytul Fatih: Cezalandırma Amacıyla Mirasçılıktan Çıkarma, Yayınlanmamış Yüksek Lisans Tezi, İstanbul, Marmara Üniversitesi Sosyal Bilimler Enstitüsü, 2008; BAYDAR, Utku: Türk Medeni Kanununa Göre Mirasçılıktan Çıkarma, Yayınlanmamış Yüksek Lisans Tezi, İstanbul, İstanbul Üniversitesi Sosyal Bilimler Enstitüsü, 2005; ÇAKIN, Nur: "Türk Hukukunda Mirastan Iskat ile İlgili Problemler", Ankara Barosu Dergisi, S.3, 1974, ss.523-536; ŞENOCAK, Zarife: "Cezai Iskat ve Cezai Iskatın Hükümleri”, Prof. Dr. Ali Bozer'e Armağan, Banka ve Ticaret Hukuku Araştırma Enstitüsü, Ankara 1998, ss.421-429.

${ }^{56}$ YAĞCI, s.33; ÇUBUKGİL, 1950, s.443; SEZEN, s.7, 46; BAYDAR, s.5-6. Ayrıca bkz. SEROZAN/ENGIN, s.398, N.183: "Mirasçılıktan çıkarma (exheredation) ... yasal mirasçının saklı payını elinden alır. Bu ă̆ırlı̆̆ ile de tipik bir özel hukuk cezası oluşturur. MK 510-512 kurallarında düzenlenmiş olan bu cezayı haklı kılan düşünce şudur: Miras bırakanı bir eliyle arkadan hançerleyen saklı paylı hısım veya eş öteki eliyle miras talep etmeye kalkışmamalıdır". 
karşı1ık, mirasçılıktan çıkarmanın, aile hukukundan doğan hak ve yükümlülüklere bir etkisinin olmadığı ifade edilmektedir ${ }^{57}$.

TMK md.511 f.1 hükmü uyarınca, mirasçılıktan çıkarılan kimse, beklenen miras hakkını kaybeder ${ }^{58}$. TMK md.511 f.2 hükmü uyarınca, "Mirasbırakan başka türlü tasarrufta bulunmadıkça mirasçıllktan çıkarllan kimsenin miras payl, o kimse mirasbırakandan önce ölmüş gibi mirasçılıktan çıkarılanın varsa altsoyuna, yoksa mirasbırakanın yasal mirasçılarına kalır". Buna göre, mirasçılıktan çıkarmada, kural olarak mirasçılıktan çıkarılan saklı paylı mirasçı da dikkate alınarak, saklı paylar hesaplanır; mirasçılıktan çıkarılan saklı paylı mirasçıya isabet eden saklı pay oranı, mirasbırakanın tasarruf oranına (nisabına) eklenir ${ }^{59}$. Buna karşı1ık TMK md.511 f.3 hükmü uyarınca, "Mirasçıllktan çıkarılan kimsenin altsoyu, o kimse mirasbırakandan önce ölmüs gibi sakl payın isteyebilir". $\mathrm{Bu}$ durumda, mirasçılıktan çıkarılan kimsenin altsoyu bulunmuyorsa veya mirasçılıktan çıkarılanın altsoyu saklı paylı mirasçı değilse mirasçılıktan çıkarılanın saklı payı, mirasbırakanın tasarruf oranına (nisabına) eklenir. Böylelikle mirasbırakanın terekesinin tasarruf edilebilir kısmı genişler ${ }^{60}$.

\section{Mirastan Feragat Halinde}

Mirastan feragat, gelecekte mirasçı olma ihtimali bulunan bir kişinin, beklenen miras hakkından, mirasın açılmasından yani mirasbırakanın ölümünden önce vazgeçmesi olarak tanımlanabilir ${ }^{61}$. Mirasın açılmasından yani mirasbırakanın ölümünden sonra mevcut miras hakkından vazgeçme ise ancak mirasın reddedilmesiyle mümkündür ${ }^{62}$.

\footnotetext{
${ }^{57}$ YAĞCI, s.358. Ayrıca bkz. HATEMİ, Hüseyin: Miras Hukuku, 7. Bas1, Vedat, İstanbul 2018, s.124, N.34: "Iskat (mirasçılıktan çıkarma) (TMK. 510) ve mahrumiyet (mirastan yoksunluk) (TMK. 578) kan hisımlı̆̆ına değil sadece mirasçılı̆̆a son verir, ıskat edilenin veya mahrum kalanın mirasçı olmasını önlerler". Bazı yazarlara göre, mirasbırakan mirasçılıktan çıkardığı mirasçısına ölüme bağlı tasarrufla bir mal vasiyeti dahi yapabilir. Çünkü mirasçılıktan çıkarmada mirasçı, mirasçı olma ehliyetini kaybetmemiştir. Bkz. ÖZTAN, 2014, s.160; ÖZUĞUR, Ali İhsan: "Miras Hakkından Iskat", Ankara Barosu Dergisi, S.3, 1996, s.349. Mirasçılıktan çıkarmanın hüküm ve sonuçları bakımından temkinli bir yaklaşım için bkz. SERT, Selin: "Mirasçılıktan Çıkarmanın Nafaka Yükümlülügüne Etkisi”, Türkiye Adalet Akademisi Dergisi, C.5, S.16, 2014, s.240.

${ }^{58}$ IMRE/ERMAN, s.254.

${ }^{59}$ DURAL/ÖZ, N.1180; İMRE/ERMAN, s.255; YAĞCI, s.468.

${ }^{60}$ KOCAYUSUFPAŞAOĞLU, s.408; İMRE/ERMAN, s.255; DURAL/ÖZ, N.1183.

${ }^{61}$ ANTALYA, Gökhan: Mirastan Feragat Sözleşmesi, 1. Bası, Alkım, İstanbul 1999, s.29; ANTALYA/SAĞLAM, s.228; DURAL/ÖZ, N.880; ALBAŞ, s.535.

${ }^{62}$ ANTALYA/SAĞLAM, s.228; İMRE/ERMAN, s.198.
} 
Mirasbırakan ile müstakbel ve muhtemel bir mirasçısı arasında yapılacak bir miras sözleşmesi ile bu sözleşmenin tarafi olan müstakbel ve muhtemel mirasçı, beklenen miras payından feragat edebilir. Mirastan feragat sözleşmesi, miras sözleşmesi ş̧eklinde yapılır. Aksi takdirde mirastan feragat sözleşmesi geçersiz olur ${ }^{63}$.

Mirastan feragat sözleşmesinin tarafları, mirasbırakan ile mirasbırakanın müstakbel ve muhtemel mirasçısıdır. Bu noktada önemle belirtmek gerekir ki mirastan feragat sözleşmesi mirasbırakanın müstakbel ve muhtemel her türlü mirasçısı ile yapılabilir ${ }^{64}$. Ancak saklı paylı mirasçılar dışındaki yasal mirasçılar ile mirastan feragat sözleşmesi yapmak gereksizdir ${ }^{65}$. Zira mirasbırakan, saklı paylı mirasçıları dışında kalan yasal mirasçılarının payları üzerinde zaten dilediği gibi tasarrufta bulunabilir. Buna karşılık, mirasç1lıktan çıkarma sebebi bulunmadıkça veya mirastan feragat sözleşmesi yapmadıkça, mirasbırakan saklı paylı mirasçılarının saklı payları üzerinde tasarrufta bulunamaz ${ }^{66}$. Başka bir deyişle, mirasçılıktan çıkarılabilmesi için geçerli bir sebep bulunmayan müstakbel ve muhtemel saklı paylı mirasçının beklenen saklı payı üzerinde mirasbırakan ancak bu mirasçının saklı payından kendi isteğiyle feragat etmesi halinde tasarrufta bulunabilir. Zaten mirastan feragat sözleşmesinin amac1, mirasbırakanın tasarruf özgürlüğünü genişletmek ve tasarruf oranını (nisabinı) artırmaktır ${ }^{67}$.

Mirastan feragat sözleşmesi, ivazlı veya ivazsız olabilir (TMK md.528 f.1). Mirastan feragat eden mirasçılık sıfatını kaybeder (TMK md.528 f.2). Mirastan feragat ivazlı olarak yapılmışsa, sözleşmede aksi

${ }^{63}$ YİBK, 11.2.1959, 16/14: “... kanunumuza göre mirastan feragat mukavelesi, miras mukavelesinin bir nevinden ibarettir. Bu itibarla mirastan feragat mukavelesinin (bütün miras mukaveleleri gibi) Medeni Kanunun 492. maddesi hükmünce resmi vasiyet şeklinde yapılması gerektir" (http://www.kazanci.com, 21 Mart 2017); Yarg. 7. HD., 20.12.1990, 16105/15573: "Mirastan feragat sözleşmesinin geçerli olabilmesi için, miras sözleşmeleri gibi resmi vasiyet şeklinde yapılması gerekir" (http://www.kazanci.com, 21 Mart 2017); Yarg. 2. HD., 22.1.2009, 15407/507: "Davalılar, davacının mirasbırakan ile yaptığı sözleşme nedeniyle, mirastan pay alamayacağını ileri sürmüşlerdir. Mirastan feragat sözleşmesinin resmi şekilde yapılması geçerlilik koşuludur (TMK. md.545). Miras haklarından feragat ancak resmi şekilde yapılacak bir sözleşme ile sonuç doğurur. Mirasbırakan ile davacı arasında mirasbırakanın sağlığında 28.10.1995 tarihinde adi yazılı şekilde düzenlenen sözleşme mirastan feragat niteliğinde değildir" (http://www.kazanci.com, 21 Mart 2017).

${ }^{64}$ DURAL/ÖZ, N.886; ALBAȘ, s.536.

65 IMRE/ERMAN, s.198; DURAL/ÖZ, N.888; ALBAŞ, s.536-537.

${ }^{66}$ DURAL/ÖZ, N.889; ALBAŞ, s.542.

${ }^{67}$ ALBAŞ, s.537, 542. 
öngörülmedikçe, feragat edenin altsoyunu da etkiler (TMK md.528 f.3). Yani feragat edenin altsoyu, mirasbırakanın saklı paylı mirasçısı olsa dahi kök içinde halefiyet ilkesi uyarınca feragat edenin yerini alarak, saklı payını talep edemez ${ }^{68}$. Buna karşıllk, ivazsız feragat, feragat edenin altsoyunu etkilemez. Yani feragat edenin yerine onun altsoyu geçer. Peki, mirastan feragat, mirasbırakanın tasarruf oranını (nisabını) nasıl etkiler? Acaba mirasbırakanın tasarruf özgürlüğünü genişletir mi?

Hem ivazlı hem de ivazsız feragat, mirasbırakanın tasarruf oranını (nisabını) genişletebilir ${ }^{69}$. Zira mirastan feragat halinde, kural olarak feragat eden saklı paylı mirasçı da dikkate alınarak, saklı paylar hesaplanır; mirastan feragat eden saklı paylı mirasçıya isabet eden saklı pay oranı, mirasbirakanın tasarruf oranına (nisabına) eklenir ${ }^{70}$. Ancak ivazsız feragat, feragat edenin altsoyu bakımından hüküm ve sonuç doğurmayacağından, ivazsız feragatte, feragat edenin altsoyunun saklı paylı mirasçı olması halinde, mirasbırakanın tasarruf oranı (nisabı) değişmez ${ }^{71}$. Çünkü mirasçılıktan çıkarmada olduğu gibi, ivazsız feragatte de feragat edenin altsoyu, o kimse mirasbırakandan önce ölmüş gibi saklı payını isteyebilir ${ }^{72}$. Buna karşılık, ivazsız feragatte, feragat edenin altsoyu bulunmuyorsa veya feragat edenin altsoyu saklı paylı mirasçı değilse feragat edenin saklı payı, mirasbırakanın tasarruf oranına (hesabına) eklenir. Böylelikle mirasbırakanın tasarruf özgürlüğü genişler ${ }^{73}$.

TMK md.508 uyarınca, "Mirasbırakanın sağlararası karşılıksız kazandırmaları, tenkise tabi oldukları ölçüde, tasarruf edilebilir kısmın hesabında terekeye eklenir". Bunun yanı sıra, TMK md.565 b.2 hükmü uyarınca, miras haklarının ölümden önce tasfiyesi maksadıyla yapılan kazandırmalar, ölüme bağlı tasarruflar gibi tenkise tabidir. Buna göre, ivazlı feragatte, mirasbırakanın müstakbel ve muhtemel saklı paylı mirasçısına ödemiş olduğu ivaz, tasarrufa esas terekenin hesabında terekeye eklenir. $\mathrm{Bu}$ durumda, öncelikle mirasbırakanın tasarrufa esas terekesi artar. Mirasbırakanın tasarrufa esas terekesinde meydana gelen bu artış, elbette mirasbırakanın terekesinin tasarruf edilebilir kısmını

\footnotetext{
${ }^{68}$ DURAL/ÖZ, N.897; İMRE/ERMAN, s.200.

69 KOCAYUSUFPAŞAOĞLU, s.410; İMRE/ERMAN, s.245; ANTALYA/SAĞLAM, s.285; ANTALYA, s.192.

${ }^{70}$ ANTALYA, s.192; ANTALYA/SAĞLAM, s.285; İMRE/ERMAN, s.245; DURAL/ÖZ, N.1188.

${ }^{71}$ İMRE/ERMAN, s.245; DURAL/ÖZ, N.1189; ANTALYA/SAĞLAM, s.288.

${ }^{72}$ ANTALYA/SAĞLAM, s.288; ANTALYA, s.192-193, 195.

${ }^{73}$ IMRE/ERMAN, s.245; ANTALYA/SAĞLAM, s.287-288; ANTALYA, s.195.
} 
çoğaltacaktır ${ }^{74}$. Bunun yanı sıra, mirastan feragat halinde, kural olarak feragat eden saklı paylı mirasçı da dikkate alınarak, saklı paylar hesaplanıp, mirastan feragat eden saklı paylı mirasçıya isabet eden saklı pay oranı, mirasbırakanın tasarruf oranına (nisabına) ekleneceğinden, yani diğer saklı paylı mirasçıların saklı payları değişmeyeceğinden başka bir deyişle sabit kalacağından, ivazlı feragatte mirasbırakanın tasarruf oranı (nisabı) genişler ${ }^{75}$. Feragat edenin altsoyunun bulunması ise ivazlı feragat bakımından önemli değildir. Zira mirastan feragat ivazlı olarak yapılmışsa, sözleşmede aksi öngörülmedikçe, feragat edenin altsoyunu da etkiler (TMK md.528 f.3).

\section{Mirastan Yoksunluk Halinde}

TMK md.578 hükmü mirastan yoksunluk sebeplerine ilişkindir. TMK md.578 hükmü, konuyu şu şekilde düzenlemektedir:

"Aşağıdaki kimseler, mirasçı olamayacakları gibi; ölüme bağh tasarrufla herhangi bir hak da edinemezler:

1) Mirasbırakanı kasten ve hukuka aykırı olarak öldüren veya öldürmeye teşebbüs edenler,

2) Mirasbırakanı kasten ve hukuka aykırı olarak sürekli şekilde ölüme bağll tasarruf yapamayacak duruma getirenler,

3) Mirasbırakanın ölüme bağlı bir tasarruf yapmasını veya böyle bir tasarruftan dönmesini aldatma, zorlama veya korkutma yoluyla sağlayanlar ve engelleyenler,

4) Mirasbırakanın artık yeniden yapamayacağı bir durumda ve zamanda ölüme bağll bir tasarrufu kasten ve hukuka aykırı olarak ortadan kaldıranlar veya bozanlar.

Mirastan yoksunluk, mirasbirakanin affiyla ortadan kalkar".

Örneğin, mirasbırakanı öldürmeye teşebbüs eden altsoy, mirastan yoksundur. Bu noktada önemle belirtmek gerekir ki mirastan yoksunluk kendiliğinden hüküm ifade eder; mirasbırakanın herhangi bir tasarrufta bulunmasına gerek yoktur ${ }^{76}$. Mirastan yoksunluk da mirasçılıktan çıkarma gibi mirasçıyı mirastan uzaklaştırma amacı taşır ${ }^{77}$.

74 DURAL/ÖZ, N.1188; İMRE/ERMAN, s.245; ANTALYA/SAĞLAM, s.286; ANTALYA, s.193.

75 KOCAYUSUFPAŞAOĞLU, s.410; DURAL/ÖZ, N.1188; İMRE/ERMAN, s.245; ANTALYA/SAĞLAM, s.286; ANTALYA, s.193-194.

76 ENGIN, Baki İlkay: Mirastan Yoksunluk, 1. Bas1, Beşir, İstanbul 2010, s.168; SEROZAN/ENGIN, s.465, N.33a; DURAL/ÖZ, N.1516; HATEMİ, s.125, N.39; 
TMK md.579 hükmü uyarınca, "Mirastan yoksunluk, yalnız yoksun olan etkiler. Mirastan yoksun olanin altsoyu, mirasbirakandan önce ölen kimsenin altsoyu gibi mirasçı olur". Buna göre, mirastan yoksun olanın altsoyunun saklı paylı mirasçı olması halinde, mirastan yoksun olan kimsenin altsoyu, o kimse mirasbırakandan önce ölmüş gibi saklı payını isteyebilir. Bu ihtimalde, mirasbırakanın tasarruf oranında (nisabında) herhangi bir değişiklik meydana gelmez. Buna karşıllk mirastan yoksun olan kimsenin altsoyu bulunmuyorsa veya mirastan yoksun olan kimsenin altsoyu saklı paylı mirasçı değilse mirastan yoksun olanın saklı payı, mirasbırakanın tasarruf oranına (nisabına) eklenir. Böylelikle mirasbırakanın terekesinin tasarruf edilebilir kısmı genişler ${ }^{78}$.

Öte yandan bazı yazarlara göre ${ }^{79}$, mirastan yoksunluk halinde mirasbırakanın tasarruf oranı, mirasın reddinde olduğu gibi hesaplanmalıdır. Oysa mirastan yoksunluk kurumunun mirasçılıktan çıkarma kurumunun tamamlayıcısı olduğu düşünüldüğünde, mirastan yoksunluk halinde mirasbırakanın tasarruf oranının (nisabının), mirasçılıktan çıkarmada olduğu gibi hesaplanması daha uygun olur ${ }^{80}$.

\section{Artık Değere (TMK md.237 f.2) ve Ortaklık Mallarına (TMK md.276 f.3) Katılma Anlaşmaları Yapılmış Olması Halinde}

Mirastan feragat sözleşmesi yapılmamış ve mirasçılıktan çıkarma veya mirastan yoksunluk sebeplerinden birinin gerçekleşmemiş olmasına rağmen bazı saklı paylı yasal mirasçıların saklı payından mahrum bırakılabilmesi, TMK md.237 f.2 ve TMK md.276 f.3 hükümleri kapsamında yapılan mal rejimi sözleşmeleriyle mümkündür. Şöyle ki TMK md.237 f.1 hükmü uyarınca, artık değere katılmada mal rejimi sözleşmesiyle başka bir esas kabul edilebilir. TMK md.237 f.2 hükmüne göre ise bu tür anlaşmalar, eşlerin ortak olmayan çocuklarının ve onların altsoylarının saklı paylarını zedeleyemez. Buna göre, miras hukuku hükümleri uyarınca söz konusu olan saklı paylı mirasçılık korumasından, yalnızca eşlerin ortak olmayan çocukları ve bunların altsoyları yararlanır. Buna karşılık eşlerin ortak çocukları ile bunların altsoyları ve ikinci zümrede yer alan saklı paylı mirasçıları yani ölen eşin ana ve babası,

İMRE/ERMAN, s.309; KILIÇOĞLU, 2018， s.266; AYAN, s.185-186, 260, 261;

ÖZTAN, 2014, s.369; ANTALYA/SAĞLAM, s.321.

${ }^{77}$ ENGIN, s.6; DURAL/ÖZ, N.1515; SEROZAN/ENGIN, s.464, N.32.

${ }^{78}$ KOCAYUSUFPAŞAOĞLU, s.411; İMRE/ERMAN, s.313-314.

${ }^{79}$ SARI, 2016, s.90; ANTALYA/SAĞLAM, s. 289.

${ }^{80}$ KOCAYUSUFPAŞAOĞLU, s.411; İMRE/ERMAN, s.314. 
miras hukuku hükümleri ile kendilerine bahşedilen saklı paylı mirasçılık korumasından yararlanamaz. Ayrıca TMK md.276 hükmü uyarınca, eşlerden birinin ölümü veya diğer bir mal rejiminin kabulü sebebiyle mal ortaklığının sona ermesi hâlinde, her eșe veya mirasçılarına ortaklık mallarının yarısı verilir; mal rejimi sözleşmesiyle başka bir paylaşma oranı kararlaştırılabilir; bu tür anlaşmalar altsoyun saklı paylarını zedeleyemez. Buna göre, miras hukuku hükümleri uyarınca söz konusu olan saklı paylı mirasçılık korumasından, yalnızca ölen eşin altsoyu yani birinci zümrede yer alan saklı paylı mirasçıları yararlanır. Buna karşılık ölen eşin ikinci zümrede yer alan saklı paylı mirasçıları yani ana ve babası, miras hukuku hükümleri ile kendilerine bahşedilen saklı paylı mirasçılık korumasından yararlanamaz ${ }^{81}$. Görüldüğü üzere, TMK md.237 f.2 ve TMK md.276 f.3 hükümleri saklı paylı yasal mirasçılık kurumunu sulandırıp zayıflatmaktadır.

Saklı paylı yasal mirasçılık kurumunun kabul edilmesinin sebebi, mirasbırakan ile bazı yasal mirasçılar arasındaki sıkı aile bağlarıdır. Buna karş1lı TMK md.237 f.2 ve TMK md.276 f.3 hükümleri, bu bağları göz ard1 etmektedir. Kald1 ki yasal mal rejimi ile kanun koyucunun her şeyi matematiksel bir yaklaşımla ele aldığı; bu yaklaşım tarzının ise toplumsal gerçeklerle bağdaşmadığı çünkü ailenin yalnızca eşler için kurulan bir kurum olmadığı; çocukların da aileyi oluşturan bireylerden olduğu ve kanun koyucunun ailenin bütün bireylerine karşı eşit mesafede durması gerektiği doktrinde ${ }^{82}$ daha önce de ifade edilmiştir.

Dikkat edilmesi gereken bir diğer husus, mal rejimi sözleşmelerinin tarafları ve bu sözleşmelerin etki alanıdır. Mal rejimi sözleşmeleri, eşler arasında yapılır. Ancak TMK md.237 f.2 ve TMK md.276 f.3 hükümleri kapsamında yapılan mal rejimi sözleşmeleri, üçüncü kişilerin yani ortak olmayan altsoyun veya ölen eşin ana ve babasının beklenen miras payları üzerinde de etkili olur. Bu durum, şüphesiz sözleşmelere hâkim olan nispilik ilkesi bakımından sorunludur ${ }^{83}$.

${ }^{81}$ IMRE/ERMAN, s.237; ARBEK, s.50.

${ }^{82}$ AKKANAT, Halil: "Yasal Mal Rejimi Değişikliğine Eleştirel Bir Yaklaşım", Hukuki Perspektifler Dergisi, S.1, 2004, s.55-56.

${ }^{83} \mathrm{Bu}$ durum, ivazsız olarak yapılan mirastan feragat sözleşmesine ilişkin bir tartışmayı hatırlatmaktadır. Şöyle ki TMK md.528 f.3 hükmü uyarınca, bir karşılık sağlanarak mirastan feragat, sözleşmede aksi öngörülmedikçe feragat edenin altsoyu için de sonuç doğurur. Bu hükümde geçen "aksi öngörülmedikçe" ifadesinin kapsamı tartışmalıdır. Şüphesiz bu hükme göre, ivazlı olarak yapılan mirastan feragat sözleşmesinin, feragat edenin altsoyu bakımından sonuç doğurmayacağı kararlaştırılabilir. Acaba ivazsız olarak 


\section{MIRASÇILAR ARASINDA EŞITLIIĞİN SAĞLANMASI: DENKLEŞTIRME}

Mirasta denkleştirme TMK md.669 ve devamı hükümlerinde düzenlenmektedir. TMK md.669 f.1 hükmü uyarınca, "Yasal mirasçılar, mirasbırakandan, miras paylarına mahsuben elde ettikleri sağlararast karşılıksız kazandırmalarl, denkleştirmeyi sağlamak için terekeye geri vermekle birbirlerine karşı yükümlüdürler". Buradan şu sonuca ulaşılmaktadır: mirasbırakanın terekesi yalnızca ölümü anında mevcut olan malvarlığı değerlerinden ibaret değildir ${ }^{84}$. Zira mirasbırakanın sağlığında yapmış olduğu karşıllıksız kazandırmalar, yasal mirasçıların paylarını azaltır. Bu noktada önemle belirtmek gerekir ki mirasbırakanın sağlığında yapmış olduğu bütün karşılıksız kazandırmalar, denkleştirmeye tabi değildir. Yalnızca yasal mirasçıların mirasbırakandan karşılıksız olarak elde ettiği menfaatler denkleştirmeye tabidir ${ }^{85}$.

Miras hukukunda denkleştirmenin amacı, mirasçılar arasında eşitliğin sağlanmasıdır ${ }^{86}$. TMK md. 669 f.2 hükmü uyarınca, "Mirasbirakanin çeyiz veya kuruluş sermayesi vermek ya da bir malvarlığını devretmek veya borçtan kurtarmak ve benzerleri gibi karşılık almaksızın altsoyuna yapmış olduğu kazandirmalar, aksi mirasbirakan tarafindan açıkça belirtilmiş olmadıkça denkleştirmeye tabidir". Görüldüğü üzere, altsoy lehine yapılan karşılıksız kazandırmalar, kendiliğinden denkleştirmeye tabidir ${ }^{87}$. Altsoy lehine yapılan karşı1ıksız

yapılan mirastan feragat sözleşmesinin, feragat edenin altsoyu bakımından sonuç doğuracağı kararlaştırılabilir mi? Bazı yazarlara göre, feragat ivazsız ise yapılan sözleşme, feragat edenin altsoyunu etkilemez ancak aksi kararlaştırılabilir (KOCAYUSUFPAŞAOĞLU, s.302; İMRE/ERMAN, s.200). Buna karşıllk bazı yazarlara göre, feragat ivazsız ise feragat edenin altsoyunun da mirasçı olamayacağı yönünde bir anlaşma yapılamaz (DURAL/ÖZ, N.898). "Çünkü, ivazlı feragatte aksinin kararlaştırllması altsoyun lehine bir durum yaratır. Buna karşılık ivazsız feragatte durum tamamen aksine olup, altsoy, kanunun kendisine tanıdiğ bir haktan mahrum birakılmaktadır. Nihayet bir kimsenin sahip olduğu bir haktan, onun adına başkasının vazgeçmesi hukuk mantığına da aykırıdır. ... ivazsız feragatin altsoyu etkileyeceği kararlaştırllabilirse, onlar kanunun kendilerine tanıdı̆̆ haktan yoksun kalacaklardır ki, bu da kendi iradelerinin dışında olacaktır"(Naklen: DURAL/ÖZ, N.898).

${ }^{84}$ IMRE/ERMAN, s.512.

${ }^{85}$ DURAL/ÖZ, N.1347.

${ }^{86}$ KOCAYUSUFPAŞAOĞLU, s.441; TURAN BAŞARA, s.19-20; TURANBOY, s.29; İMRE/ERMAN, s.512; KILIÇOĞLU, 2018, s.469; AYAN, s.309; SEROZAN/ENGIN, s.586, N.39a; ANTALYA/SAĞLAM, s.451; ÖZTAN, 2014, s.506.

87 ANTALYA/SAĞLAM, s.456. Ancak denkleştirme yükümlüsü, denkleştirmeden kaçıyorsa elbette denkleştirme alacaklısının bir dava ile denkleştirmenin yapılmasını sağlaması gerekir (DURAL/ÖZ, N.1423). Bu noktada sağ kalan eşin, mirasbırakanın 
kazandırmalar, yalnızca mirasbırakan tarafından $a c ̧ ı k c ̧ a$ belirtilmiş olması halinde denkleştirmeden kurtulurlar. Buradan hareketle miras hukukunda denkleştirmenin asıl amacının, altsoy arasında eşitliği sağlamak olduğu sonucuna ulaşılmaktadır ${ }^{88}$. Buna karşılık, TMK md.237 f.2 hükmünde ortak altsoy ve ortak olmayan altsoy ayırımı yapıldığı görülmektedir. Böylelikle mirasbırakanın birinci zümre yasal mirasçıları yani altsoyu arasındaki eşitlik bozulmaktadır ${ }^{89}$. Bu noktada bir hususa dikkat etmek gerekir. İlgili hüküm dolayısıyla saklı payını dahi alamayan ortak altsoyun, mirasbırakandan elde ettiği sağlararası karşılıksız kazandırmayı terekeye iade etme yükümlülügü TMK md.669 f.2 hükmü uyarınca devam eder.

Mirasbırakanın sağlığında yapmış olduğu kazandırmaların tespit edilmesi her zaman kolay değildir. Bu durumu öngören kanun koyucu, mirasçılara bir bilgi verme yükümlülüğü getirmiştir. Buna ilişkin düzenleme, TMK md.649 f.2 hükmüdür. Bu hükme göre, "Mirasçılar, mirasbırakan ile aralarındaki iliş̧kiler hakkında paylaşmanın eşitliğe ve adalete uygun olması için göz önüne alınması gereken bütün bilgileri birbirlerine vermekle yükümlüdürler". $\mathrm{Bu}$ hüküm karşısında, mirasbırakandan denkleştirmeye tabi sağlararası karşılıksız kazandırma elde eden bir yasal mirasçının bu durumu diğer yasal mirasçılara bildirmesi gerekir. Aksi takdirde bilgi verme yükümlülüğünü ihlal eden yasal mirasçı, TBK md.112 uyarınca, diğer yasal mirasçıların bu ihlal nedeniyle uğramış olduğu zararı gidermekle yükümlü olur ${ }^{90}$. Buna göre, TMK md.237 f.2 hükmü uyarınca saklı payını dahi alamayan buna karşı1ık mirasbırakandan elde ettiği sağlararası karşı1ıksız kazandırmayı terekeye iade etme yükümlülüğ̈̈ devam eden ortak altsoyun, TMK md.649 f.2 hükmü uyarınca diğer yasal mirasçılara bu hususa ilişkin bilgi verme yükümlülüğü de devam eder; eğer ortak altsoy mirasbirakandan elde ettiği sağlararası karşı1ıksız kazandırmayı diğer yasal mirasçılardan

altsoyuyla birlikte mirasçı olması halinde denkleştirme alacaklısı olup olamayacağı tartışlabilir. $\mathrm{Bu}$ konu hakkında detaylı bilgi için bkz. GÜRPINAR, Damla: "Mirasbırakanın Sağlığında Altsoyuna Yaptığı Karşılıksız Kazandırmaların Denkleştirilmesinde Sağ Kalan Eşin Durumu”, Ankara Barosu Dergisi, S.4, 2017, s.105139.Yazara göre, "Mirasbırakanın bu yönde bir irade açıklaması olmadı̆̆ı sürece, să̆ kalan eş altsoy karşısında denkleş̧irme alacaklısı olabilmelidir" (s.135).

${ }^{88}$ IMRRE/ERMAN, s.512; KOCAYUSUFPAŞAOĞLU, s.444; DURAL/ÖZ, N.1367.

${ }^{89}$ Edinilmiş mallara katılma rejiminin aile bireyleri arasında eşitliği sağlamaktan uzak olduğu ve aile bireyleri arasında adaletsizlik meydana getirdiği ileri sürülmektedir (AKKANAT, Mal Rejimi, s.56).

${ }^{90}$ DURAL/ÖZ, N.1959. 
saklarsa yani bilgi verme yükümlülüğ̈̈nü ihlal ederse böyle bir durumda TBK md.112 uyarınca, diğer yasal mirasçıların bu ihlal nedeniyle uğramış olduğu zararı gidermekle yükümlü olur.

Miras hukukunda denkleştirmenin asıl amacının altsoy arasında eşitliği sağlamak olduğu; mal rejimlerine ilişkin TMK md.237 f.2 hükmünde ise ortak altsoy ve ortak olmayan altsoy ayırımı yapıldığı ve eşler arasında yapılan mal rejimi sözleşmeleriyle eşlerin ortak çocuklarının ve onların altsoylarının kısmen veya tamamen saklı paylarından mahrum bırakılabileceği dikkate alındığında, TMK md.669 f.2 hükmüyle tesis edilmeye çalışılan altsoy arasındaki eşitliğin başka bir kanun hükmüyle bozulduğu yani TMK md.237 f.2 hükmünün, TMK md.669 f.2 hükmüyle çeliştiği görülmektedir. TMK md.237 f.2 hükmü uyarınca saklı payını dahi alamayan ortak altsoyun TMK md.669 f.2 hükmü uyarınca mirasbırakandan elde ettiği sağlararası karşılıksız kazandırmayı terekeye iade etme yükümlülüğünün devam etmesi ve TMK md.649 f.2 hükmü uyarınca söz konusu olan bilgi verme yükümlülüğünü ihlal etmesi halinde TBK md.112 uyarınca, diğer yasal mirasçıların bu ihlal nedeniyle uğramış olduğu zararı gidermekle yükümlü olması ise hakkaniyete aykırıdır.

\section{MIRASÇILARIN MIRASBIRAKANIN BORÇLARINDAN SORUMLULUĞU}

TMK md.599 f.2 hükmünde,“ ... mirasçılar, ... mirasbırakanın borçlarından kişisel olarak sorumlu olurlar" denmektedir. TMK md.641 f.1 hükmünde ise "Mirasçılar, tereke borçlarından müteselsilen sorumludurlar" ifadesine yer verilmiştir. Buna göre, mirasçılar mirasbırakanın borçlarının tamamından müteselsil ve sınırsız olarak kişisel malvarlıklarıyla sorumlu olurlar ${ }^{91}$. Bu sorumluluk, mal rejimi sözleşmeleri nedeniyle saklı payını alamayan mirasçılar bakımından da söz konusudur. Zira bu kişilerin, mirasçılık sıfatı devam etmektedir.

Önemle belirtmek gerekir ki evlilik birliğinin eşlerden birinin ölümüyle sona ermesi halinde, sağ kalan eşin, artık değerin tamamı üzerinde hak sahibi olacağına ilişkin bir mal rejimi sözleşmesi yapılmışsa ve ölen eşin terekesinin aktifi yalnızca edinilmiş mallardan oluşuyorsa böyle bir durumda, sağ kalan eş dışındaki mirasçıların ölen eşin mirasından hiçbir şey alamaması buna karşılık mirasbırakanın borçlarını ödemesi ihtimali ortaya çıkar. Bu ihtimalin gerçekleşmesi halinde ise mirasçılar, mirası reddetme yoluna giderler. Zira mal rejimi sözleşmesi

\footnotetext{
${ }^{91}$ İMRE/ERMAN, s.455; DURAL/ÖZ, N.1890; BAYGIN, s.52-53.
} 
nedeniyle saklı payını alamayan bu mirasçılar için tereke adeta borca batıktır; bu mirasçılar için terekede yalnızca borç vardır. Saklı payını alamayan mirasçıların, mirası reddetme yoluna gitmesi ise mirasbırakanın alacaklıları bakımından olumsuz sonuçlar doğurur. Zira mirasbırakanın alacaklılarının başvurabileceği kişi sayısı azalmış olur.

\section{SONUÇ}

Artık değere (TMK md.237 f.2) ve ortaklık mallarına (TMK md.276 f.3) katılma anlaşmalarına ilişkin düzenlemelerin, miras hukuku sistemimiz karşısındaki durumunun çeşitli yönlerden incelenmesi neticesinde, bu düzenlemelerin, Türk Medeni Kanunu'nda benimsenen miras hukuku sistemiyle ve sözleşmelere hâkim olan nispilik ilkesi ile bağdaşmadığı kanaatine ulaşılmaktadır. Bu durumun, gerçek olmayan kanun boşluğunun varlığından kaynaklandığı düşünülmektedir. Zira bir hükmün somut olaya olduğu gibi uygulanmasının kanunun amacına ve menfaatler dengesine aykırı düşmesi halinde, gerçek olmayan kanun boşluğu söz konusu olur. Başka bir deyişle, hükmün uygulanması halinde tatmin edici olmayan sonuçlar meydana gelir ${ }^{92}$. Bazı yazarlara göre ${ }^{93}$, bu durum kanundaki düzenlemenin yetersizliğinden ileri gelir. Gerçek olmayan bir kanun boşluğunun söz konusu olması halinde ise hâkim hukuk yaratarak bu boşluğu dolduramaz; böyle bir hükmü düzeltmek kanun koyucunun işidir ${ }^{94}$.

Yeni Medeni Kanun'da saklı pay oranlarının indirilmesiyle mirasbırakanın tasarruf özgürlüğünün genişlediği ${ }^{95}$; zaman içinde sağ kalan eşe verilen önemin $\operatorname{arttı̆g}{ }^{96}$ ve mirasbırakan tarafindan altsoy dışındaki yasal mirasçılara yapılan sağlararası karşılıksız kazandırmaların, mirasbırakan tarafindan aksi belirtilmiş olmadıkça denkleştirmeye tabi olmadığı dikkate alındığında, eşler arasındaki mal rejiminin mal ortaklığı olduğu hallerde, mal rejimi sözleşmesiyle kanunda öngörülen paylaşma oranından başka bir paylaşma oranının kararlaştırılabileceğini düzenleyen

${ }^{92}$ DURAL, Mustafa/ SARI, Suat: Türk Özel Hukuku, Cilt: I: Temel Kavramlar ve Medeni Kanunun Başlangıç Hükümleri, 12. Bası, Filiz, İstanbul 2017, N.868.

${ }^{93}$ AKİPEK, Jale G./ AKINTÜRK, Turgut / ATEŞ KARAMAN, Derya: Türk Medeni Hukuku Başlangıç Hükümleri Kişiler Hukuku, 11. Bası, Beta, İstanbul 2014, s. 127.

${ }^{94}$ DURAL/SARI, N.868.

${ }^{95}$ Detaylı bilgi için bkz. KILIÇOĞLU, Ahmet: Medeni Kanun'umuzun Aile-Miras-Eşya Hukukuna Getirdiği Yenilikler, 3. Bası, Turhan, Ankara 2014, s.324 vd.; İŞGÜZAR, Hasan: Yeni Türk Medeni Kanunu’na Göre Miras Hukuku Hükümlerindeki Değişiklikler ve Yenilikler, 1. Bas1, Yetkin, Ankara 2003, s.33 vd.

${ }^{96}$ KILIÇOĞLU, 2018, s.208. 
ve bu yönde yapılan anlaşmaların altsoy dışındaki yasal mirasçıların saklı paylarını zedelemesine izin veren TMK md.276 f.3 hükmü, gerçek olmayan kanun boşluğunun varlığına rağmen makul karşılanabilir. Ancak artık değere katılma anlaşmalarına ilişkin TMK md.237 f.2 hükmü, kanun koyucu tarafından yeniden düzenlenmelidir.

Yeni bir düzenleme yapabilmek için, öncelikle TMK md.237 f.2 hükmünde, neden ortak altsoy-ortak olmayan altsoy ayırımı yapıldığ 1 üzerinde durulmalıdır. İlgili hükümde böyle bir ayırım yapılmasının nedeni, mal rejimi sözleşmesiyle bir menfaat sağlayan sağ kalan eşin, aynı zamanda ortak çocukların ana veya babası olması ve sağ kalan eşin ölümü halinde, ilk önce ölen eşin edinilmiş malvarlığ altsoya intikal edecek olmasıdır ${ }^{97}$. Ancak önemle belirtmek gerekir ki bu durum, her zaman böyle değildir. Mirastan yoksunluk, mirasçılıktan çıkarma, mirasbırakanın ölümü anında sağ olmama veya malvarlığı değerlerinin harcanması gibi ihtimaller, ortak altsoyun bu menfaatten hiçbir zaman yararlanamaması riskini taşır ${ }^{98}$. Kanun koyucunun amacı ise bu değildir; geç de olsa ortak altsoyun ilk önce ölen eşin edinilmiş malvarlığı değerlerinden pay almasıdır.

Kanun koyucunun amacının bu şekilde olduğu dikkate alındığında, artık değere katılma anlaşmalarına ilişkin yeni bir düzenleme yapılırken, artmirasçı atamaya ilişkin hükümlerden yararlanılabileceği düşünülmektedir. Bu noktada, ilk önce ölen eş ile ortak altsoy arasında kanundan doğan bir artmirasçılık ilişkisi kurulabilir. TMK md.521 f.1 hükmünde, "Mirasbırakan, ölüme bağlı tasarrufuyla önmirasçı atadığı kişiyi mirası artmirasçıya devretmekle yükümlü kılabilir" denmektedir. Benzer şekilde, sağ kalan eş de artık değere katılma anlaşması nedeniyle

\footnotetext{
${ }^{97}$ ŞENOCAK, 2009, s.381; ŞIPKA, s.278; ACAR, s.128.

98 Her ne kadar ortak çocukların TMK md.237 f.2 hükmünden yararlanmasına gerek olmadığı belirtilmiş olsa da çalışmasının devamında ACAR tarafından, şu hususlar tespit edilmiştir: "Ortak çocukların sağ kalan eşe geçen malvarlığının sonradan mirasçısı olacă̆g yönündeki yaklaşım da yeterli gözükmemektedir. Çünkü altsoyun miras yoluyla bu değerlere ulaşması kolaylıkla olmaz. Mirası elde edebilmeyi engelleyen să̆ olmama, yoksunluk, çıkarılma, ebeveyn tarafindan sağlığında malların tüketilmesi (TMK md.565) gibi riskler daima olumsuzluk yaratacaktır. Ayrıca, mal rejimi sözleşmesi her ne kadar sağlıkta yapıllyor bile olsa etkisini eşlerden birinin ölümü üzerine göstermekte, ölen eşin terekesini oluşturacak değerlerden bir kısmının diğer eşe kalmasını sağlamaktadır. Yani ölüme bağll tasarruf etkisini göstermektedir. Dolaylsılla ölüme bağll tasarruflar gibi TMK m. 505, 506'da ortaya konulan sakl pay kurallarına tabi olmasi gerekir. Diğer bir ifadeyle TMK m.237/2'nin getirdiği himayeden önceki evlilikten doğan altsoyun yan sıra, ölüm ile son bulan evlilikten doğan ortak altsoyun da yararlanması gerekir. Ortak çocukların böyle bir himayeye ihtiyaçları olabilir" (s.129).
} 
saklı payını kısmen veya tamamen alamayan ortak altsoya karşı, bu payı devretmekle yükümlü tutulabilir. Yani sağ kalan eş, önmirasçı; saklı payı kısmen veya tamamen ihlal edilen ortak altsoy ise artmirasçı gibi düşünülebilir. Bu noktada şöyle bir soru yöneltilebilir: Bu pay devri ne zaman gerçekleşecektir? TMK md.522 f.1 hükmünde, "Tasarrufta geçiş anı belirtilmemişse miras, önmirasçının ölümüyle artmirasçıya geçer" denmektedir. Kanun koyucunun amacının, artık değere katılma anlaşmalarıyla "eşlerden birinin ölümü üzerine diğerinin kalan yaşamını güvence altına almak" olduğu ${ }^{99}$ dikkate alındığında, artık değere katılma anlaşmasıyla ihlal edilen saklı payın sağ kalan eşin ölümüyle ortak altsoya geçeceği kabul edilebilir.

Yukarıda da ifade edildiği üzere, artık değere katılma anlaşmasıyla bir menfaat elde eden sağ kalan eşin ölümü halinde, ilk önce ölen eşin edinilmiş malvarlığ değerlerinin ortak altsoya geçip geçmeyeceği belli değildir. Belki de ortak altsoy bu menfaatten hiçbir zaman yararlanamayacaktır. Bu noktada, yine artmirasçlık bakımından söz konusu olan mirasin sulh mahkemesi tarafindan defterinin tutulmas1, mirasın önmirasçının güvence göstermesi halinde önmirasçıya teslim edilmesi, taşınmazlarda mirası geçirme yükümlülüğünün tapu kütüğüne şerh verilmesi ve önmirasçının güvence göstermemesi veya artmirasçının beklenen haklarını tehlikeye düşürmesi halinde mirasın resmen yönetilmesi gibi tedbirlere (TMK md.523) başvurulabilir.

\section{KAYNAKÇA}

ACAR, Faruk: Aile Hukukumuzda Aile Konutu, Mal Rejimleri, Eşin Yasal Miras Payı, 5. Bası, Seçkin, Ankara 2016.

AKINTÜRK, Turgut / ATEŞ, Derya: Aile Hukuku, 20. Bası, Beta, İstanbul 2017.

AKIPPEK, Jale G./ AKINTÜRK, Turgut / ATEŞ KARAMAN, Derya: Türk Medeni Hukuku Başlangıç Hükümleri Kişiler Hukuku, 11. Bası, Beta, İstanbul 2014.

AKKANAT, Halil: "Yasal Mal Rejimi Değişikliğine Eleştirel Bir Yaklaşım”, Hukuki Perspektifler Dergisi, S.1, 2004, s.54-57. (Mal Rejimi)

AKKANAT, Halil: Ölümün Özel Hukuk İlişkilerine Etkisi, 1. Bası, Filiz, İstanbul 2004. (Özel Hukuk)

ALBAŞ, Hakan: "Mirastan Feragat Sözleşmesi ve Hükümlerine İlişkin Bazı Sorunlar", Prof. Dr. Ünal Narmanlığlu'na Armağan, Dokuz Eylül Üniversitesi Hukuk Fakültesi Dergisi, C.9, S.Özel, 2007, ss.535-552.

ANTALYA, Gökhan / SAĞLAM, İpek: Miras Hukuku 3. Bası, Legal, İstanbul 2015. ANTALYA, Gökhan: Mirastan Feragat Sözleşmesi, 1. Bası, Alkım, İstanbul 1999.

\footnotetext{
${ }^{99}$ ŞENOCAK, 2009, s.381.
} 
ARBEK, Ömer: $\quad$ Miras Hukukunda Ölüme Bağlı İşlemlerde İrade Serbestisi Sınırları ve Müeyyidesi, 1. Bası, Yetkin, Ankara 2013.

ARIDEMİR, Arzu Genç: Mirasın Açılmasından Sonra Yapılan Miras Payının Devri Sözleşmesi, 1. Bası, On İki Levha, İstanbul 2012.

ATEŞ, Turan: $\quad$ Edinilmiş Mallara Katılma Rejimi, 3. Bası, Bilge, Ankara 2013.

AYAN, Mehmet: $\quad$ Miras Hukuku, 9. Bası, Seçkin, Ankara 2016.

BAYDAR, Utku: Türk Medeni Kanununa Göre Mirasçılıktan Çıkarma, Yayınlanmamış Yüksek Lisans Tezi, İstanbul, İstanbul Üniversitesi Sosyal Bilimler Enstitüsü, 2005.

BAYGIN, Cem: Türk Miras Hukukunda Alacaklıların Korunması, 1. Bası, Seçkin, Ankara 2005.

ÇAĞA, Tahir: Türk-İsviçre Hukukuna Göre Mahfuz Hisseli Mirasçıların Hukuki Vaziyeti, 1. Bası, İsmail Akgün Matbaası, İstanbul 1950.

ÇAKIN, Nur: "Türk Hukukunda Mirastan Iskat ile İlgili Problemler", Ankara Barosu Dergisi, S.3, 1974, ss.523-536.

ÇUBUKGİL, Rıza: "Medeni Kanunumuzda Mirastan Adi Iskatın Hüküm ve Neticeleri”, Ankara Üniversitesi Hukuk Fakültesi Dergisi, C.8, S.3-4, 1951, ss.595609. (1951)

ÇUBUKGILL, Rıza: "Mirastan Adi Iskatın Hukuki Mahiyeti ve Sebepleri”, Ankara Üniversitesi Hukuk Fakültesi Dergisi, C.7, S.3-4, 1950, ss.441-467. (1950)

DURAL, Mustafa/ ÖĞÜZ, Tufan/ GÜMÜŞ, Mustafa Alper: Türk Özel Hukuku, Cilt: III: Aile Hukuku, 13. Bas1, Filiz, İstanbul 2018.

DURAL, Mustafa / ÖZ, Turgut: Türk Özel Hukuku, Cilt: IV: Miras Hukuku, 11. Bas1, Filiz, İstanbul 2017.

DURAL, Mustafa/ SARI, Suat: Türk Özel Hukuku, Cilt: I: Temel Kavramlar ve Medeni Kanunun Başlangıç Hükümleri, 12. Bası, Filiz, İstanbul 2017.

ENGİN, Baki İlkay: Mirastan Yoksunluk, 1. Bası, Beşir, İstanbul 2010.

ERDEM, Mehmet: Aile Hukuku, 1. Bası, Seçkin, Ankara 2018.

GÖNEN, Doruk: El Yazılı Vasiyetname, 1. Bas1, Legal, İstanbul 2007.

GÜRPINAR, Damla: "Mirasbırakanın Sağlığında Altsoyuna Yaptığı Karşı1lıksız Kazandırmaların Denkleştirilmesinde Sağ Kalan Eşin Durumu”, Ankara Barosu Dergisi, S.4, 2017, s.105-139.

HATEMİ, Hüseyin / KALKAN OĞUZTÜRK, Burcu: Aile Hukuku, 2. Bası, Vedat, İstanbul 2013.

HATEMİ, Hüseyin: Miras Hukuku, 7. Bas1, Vedat, İstanbul 2018.

İMRE, Zahit / ERMAN, Hasan: Miras Hukuku, 13. Bası, Der, İstanbul 2017.

IŞGÜZAR, Hasan: Yeni Türk Medeni Kanunu'na Göre Miras Hukuku Hükümlerindeki Değişiklikler ve Yenilikler, 1. Bası, Yetkin, Ankara 2003.

KARACA, Beytul Fatih: Cezalandırma Amacıyla Mirasçılıktan Çıkarma, Yayınlanmamış Yüksek Lisans Tezi, İstanbul, Marmara Üniversitesi Sosyal Bilimler Enstitüsü, 2008.

KILIÇOĞLU, Ahmet: Aile Hukuku, 3. Bası, Turhan, Ankara 2017.

KILIÇOĞLU, Ahmet: Edinilmiş Mallara Katılma Rejimi, 2. Bası, Turhan, Ankara 2002.

KILIÇOĞLU, Ahmet: Katk1-Katılma Alacağı, 4. Bas1, Turhan, Ankara 2014. (2014) 
KILIÇOĞLU, Ahmet: Medeni Kanun'umuzun Aile-Miras-Eşya Hukukuna Getirdiği Yenilikler, 3. Bas1, Turhan, Ankara 2014.

KILIÇOĞLU, Ahmet: Miras Hukuku, 8. Bası, Turhan, Ankara 2018. (2018)

KIRMIZI, Mustafa: Açıklamalı-İçtihatlı Edinilmiş Mallara Katılma Rejimi ve Aile Konutu, 3. Bas1, Ankara 2014.

KOCAYUSUFPAŞAOĞLU, Necip: Miras Hukuku, 3. Bası, Filiz, İstanbul 1987.

KOYUNCU, Ferhat: Sözlü Vasiyetname, 1. Bası, Seçkin, Ankara 2014.

KÖSEOĞLU, Bilal / KOCAAĞA, Köksal: Aile Hukuku ve Uygulamas1, 2. Bası, Ekin, Bursa 2011.

ÖZTAN, Bilge: $\quad$ Aile Hukuku, 6. Bası, Turhan, Ankara 2015. (2015)

ÖZTAN, Bilge: $\quad$ Miras Hukuku, 6. Bas1, Turhan, Ankara 2014. (2014)

ÖZUĞUR, Ali İhsan: "Miras Hakkından Iskat”, Ankara Barosu Dergisi, S.3, 1996, ss.346353. (1996)

ÖZUĞUR, Ali İhsan: Mal Rejimleri, 1. Bası, Seçkin, Ankara 2004. (2004)

SANBERK, Mustafa Turgut: Resmi Vasiyetname, Yayınlanmamış Yüksek Lisans Tezi, İstanbul, Marmara Üniversitesi Sosyal Bilimler Enstitüsü, 2002.

SAPANOĞLU, Süleyman: Miras Paylaşma ve Miras Payının Devri Sözleşmeleri, 1. Bası, Yetkin, Ankara 2011.

SARI, Suat: $\quad$ Evlilik Birliğinde Yasal Mal Rejimi Olarak Edinilmiş Mallara Katılma Rejimi, 1. Bası, Beşir Kitabevi, İstanbul 2007. (2007)

SARI, Suat: $\quad$ Uygulamalı Miras Hukuku, 3. Bas1, Filiz, İstanbul 2016. (2016)

SEROZAN, Rona / ENGIN, Baki İlkay: Miras Hukuku, 5. Bası, Seçkin, Ankara 2018.

SERT, Selin: "Mirasçılıktan Çıkarmanın Nafaka Yükümlülüğüne Etkisi”, Türkiye Adalet Akademisi Dergisi, C.5, S.16, 2014, ss.229-243.

SEZEN, Cehdi Cihan: Türk Hukukunda Mirastan Çıkarma, Yayınlanmamış Yüksek Lisans Tezi, İstanbul, Marmara Üniversitesi Sosyal Bilimler Enstitüsü, 2008.

ŞENOCAK, Zarife: “Cezai Iskat ve Cezai Iskatın Hükümleri”, Prof. Dr. Ali Bozer'e Armağan, Banka ve Ticaret Hukuku Araştırma Enstitüsü, Ankara, 1998, ss.421-429. (1998)

ŞENOCAK, Zarife: "Edinilmiş Mallara Katılma Rejiminde Artık Değere Katılma İle İlgili Mal Rejimi Sözleşmeleri ve Tenkisi”, Ankara Üniversitesi Hukuk Fakültesi Dergisi, C.58, S.2, 2009, ss.377-411. (2009)

ŞIPKA, Şükran / KAPLAN, Hasan Ali: “4721 Sayılı Türk Medeni Kanunu’na göre Eşlerin Artık Değere Katılma ve Paylaşma Oranı ile İlgili Olarak Yapacakları Mal Rejimi Sözleşmelerinin Altsoya Etkisi”, Prof. Dr. Necip Kocayusufpaşaoğlu İçin Armağan, Ankara 2004, ss.263-274.

ŞIPKA, Şükran: Türk Hukukunda Edinilmiş Mallara Katılma Rejimi ve Uygulamaya İlişkin Sorunlar, 3. Bası, On İki Levha, İstanbul 2013.

TURAN BAŞARA, Gamze: Miras Hukukunda Denkleştirme, 1. Bası, Turhan, Ankara 2013.

TURAN, Gamze: Ölüme Bağlı Tasarrufların Hükümsüzlüğü, 1. Bası, Turhan, Ankara 2009.

TURANBOY, Kürşat Nuri: Mirasbırakanın Denkleştirme ve Tenkise Bağlı Sağlararası Hukuki İşlemleri, 1. Bası, Yetkin, Ankara, 2010. 
UZUN, Neşe: Edinilmiş Mallara Katılma Rejiminin Diğer Mal Rejimleriyle Karşılaştırılması, Yayınlanmamış Yüksek Lisans Tezi, İstanbul, Bahçeşehir Üniversitesi Sosyal Bilimler Enstitüsü, 2009.

YAĞCI, Kürşad: Cezai Mirasçılıktan Çıkarma, 1. Bası, On İki Levha, İstanbul 2013.

YAĞCIOĞLU, Ali Haydar: Edinilmiş Mallara Katılma Rejiminde Eşlerin Yasal Alım Hakk1, 1. Bası, Güncel Hukuk, İzmir, 2007.

YAZGAN, Selda: Edinilmiş Mallara Katılma Rejiminde Mal Paylaşımı, Yayınlanmamış Yüksek Lisans Tezi, Ankara, Gazi Üniversitesi Sosyal Bilimler Enstitüsü, 2014.

YILDIRIM, Abdülkerim: Türk Aile Hukuku, 1. Bası, Savaş, Ankara 2014.

ZEYTIN, Zafer: Edinilmiş Mallara Katılma Rejimi ve Tasfiyesi, 3. Bası, Seçkin, Ankara 2017. 